\title{
Methane as a diagnostic tracer of changes in the Brewer-Dobson circulation of the stratosphere
}

\author{
E. E. Remsberg \\ Science Directorate, NASA Langley Research Center, 21 Langley Blvd., Mail Stop 401B, Hampton, VA 23681, USA \\ Correspondence to: E. E. Remsberg (ellis.e.remsberg@ nasa.gov)
}

Received: 21 August 2014 - Published in Atmos. Chem. Phys. Discuss.: 18 September 2014

Revised: 24 February 2015 - Accepted: 22 March 2015 - Published: 7 April 2015

\begin{abstract}
This study makes use of time series of methane $\left(\mathrm{CH}_{4}\right)$ data from the Halogen Occultation Experiment (HALOE) to detect whether there were any statistically significant changes of the Brewer-Dobson circulation (BDC) within the stratosphere during 1992-2005. The $\mathrm{HALOE} \mathrm{CH}_{4}$ profiles are in terms of mixing ratio versus pressure altitude and are binned into latitude zones within the Southern Hemisphere and the Northern Hemisphere. Their separate time series are then analyzed using multiple linear regression (MLR) techniques. The $\mathrm{CH}_{4}$ trend terms for the Northern Hemisphere are significant and positive at $10^{\circ} \mathrm{N}$ from 50 to $7 \mathrm{hPa}$ and larger than the tropospheric $\mathrm{CH}_{4}$ trends of about $3 \%$ decade $^{-1}$ from 20 to $7 \mathrm{hPa}$. At $60^{\circ} \mathrm{N}$ the trends are clearly negative from 20 to $7 \mathrm{hPa}$. Their combined trends indicate an acceleration of the $\mathrm{BDC}$ in the middle stratosphere of the Northern Hemisphere during those years, most likely due to changes from the effects of wave activity. No similar significant BDC acceleration is found for the Southern Hemisphere. Trends from HALOE $\mathrm{H}_{2} \mathrm{O}$ are analyzed for consistency. Their mutual trends with $\mathrm{CH}_{4}$ are anti-correlated qualitatively in the middle and upper stratosphere, where $\mathrm{CH}_{4}$ is chemically oxidized to $\mathrm{H}_{2} \mathrm{O}$. Conversely, their mutual trends in the lower stratosphere are dominated by their trends upon entry to the tropical stratosphere. Time series residuals for $\mathrm{CH}_{4}$ in the lower mesosphere also exhibit structures that are anti-correlated in some instances with those of the tracer-like species $\mathrm{HCl}$. Their occasional aperiodic structures indicate the effects of transport following episodic, wintertime wave activity. It is concluded that observed multi-year, zonally averaged distributions of $\mathrm{CH}_{4}$ can be used to diagnose major instances of wave-induced transport in the middle atmosphere and to detect changes in the stratospheric BDC.
\end{abstract}

\section{Background}

The dynamically forced, seasonal circulation in the meridional plane of the stratosphere is balanced by differential radiative heating between Equator and pole. It is a measure of the diabatic circulation and is often termed the residual mean mass circulation or the transformed Eulerian mean (TEM) circulation (e.g., Dunkerton, 1978; Andrews et al., 1987). To a large degree, that primary circulation is balanced at the middle latitudes by two-way exchanges or mixing processes (Birner and Bönisch, 2011; Garny et al., 2014; Ploeger et al., 2015a). Together, both mechanisms constitute the total or Brewer-Dobson circulation (BDC), generally having an upward component at low latitudes and a return, downward component at the extratropical latitudes of both the Northern Hemisphere and the Southern Hemisphere (e.g., Butchart, 2014; Plumb, 2007; Haynes et al., 1991). The dissipation of planetary (or Rossby) waves and gravity wave forcings tends to accelerate the BDC and to enhance mixing in the winter hemisphere (e.g., Solomon et al., 1986; Plumb, 2007; Shepherd, 2007; Okamoto et al., 2011). Thus, it is likely that there is some asymmetry for the BDC in the Northern Hemisphere versus the Southern Hemisphere stratosphere because winter wave forcing and mixing processes are more pronounced and frequent in the Northern Hemisphere (Shepherd, 2007).

A schematic of the BDC and its relation to the distribution of ozone in the stratosphere is shown in Fig. 1 for March, where the solid black curves represent the sense of the circulation and the vertical orange arrow represents the approximate region for the propagation of waves from the upper troposphere and up into the middle atmosphere (see Shaw and Shepherd, 2008). Figure 1 indicates that the BDC leads to an accumulation of ozone in the extratropics of the Northern Hemisphere by March. Tracer-like molecules, such $\mathrm{N}_{2} \mathrm{O}$ and 


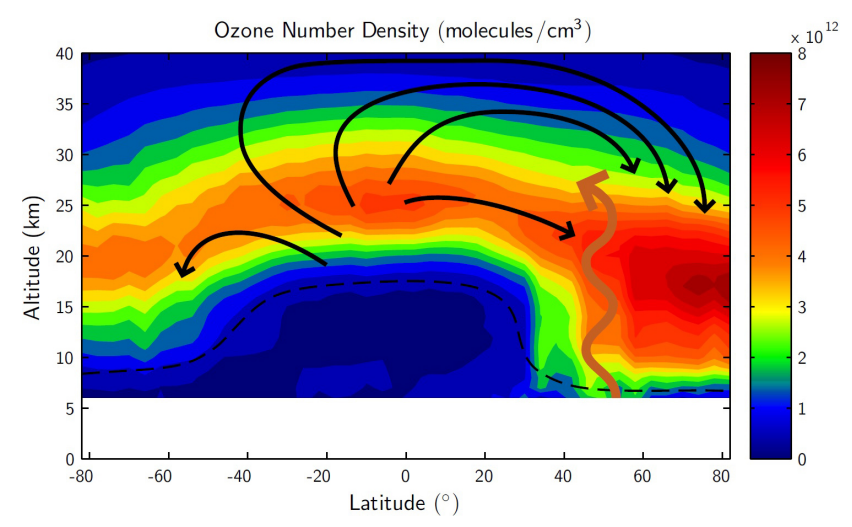

Figure 1. Brewer-Dobson circulation (BDC) and stratospheric ozone. The sense of this net circulation or BDC is shown by the black arrows overlain on the zonally averaged ozone distribution (or its number density in molecules per $\mathrm{cm}^{3}$ versus latitude and altitude) for March 2004, as measured by the OSIRIS satellite instrument. Wiggly orange arrow indicates the propagation of waves from the troposphere as they affect the ozone. The dashed black line is the tropopause (adaption of figure in Shaw and Shepherd, 2008).

$\mathrm{CH}_{4}$, exhibit distributions that are well correlated and vary seasonally in response to changes in the BDC (Plumb and Ko, 1992; Holton, 1986).

Figure 2 is an example of the zonally averaged distribution of $\mathrm{CH}_{4}$ for January from a NASA/Goddard, two-dimensional chemistry and transport model simulation (Fleming et al., 1999). The white arrows show the effects of the stratospheric $\mathrm{BDC}$, which is strong in the winter hemisphere (longer arrows) and weak in the summer stratosphere. Tracer species such as $\mathrm{CH}_{4}$ depict the mass circulation qualitatively, i.e., bulging upward in the tropics and downward at high latitudes (more so in the winter hemisphere). Figure 2 shows that the January zonal-mean circulation is in the correct sense to bring about the accumulation of ozone in the lower stratosphere by March, as shown in Fig. 1. In addition, Manney et al. (1994) emphasize that the character of the observed winter hemisphere transport and descent differs for the upper versus the lower stratosphere and depends on whether the polar vortex is undisturbed and centered on the pole or disturbed by Rossby-wave activity.

A current issue is whether the observed, seasonal BDC is changing in the presence of the steady increases in the socalled "greenhouse gases", like $\mathrm{CO}_{2}$ (e.g., Butchart, 2014). Early on, Rind et al. (1990) conducted a series of simulation studies of those effects, and their results indicated that there will be an acceleration of the BDC, particularly in the Northern Hemisphere. Lin and Fu (2013) analyzed more recent results from a collection of chemistry/climate models (CCM), and they found that the diabatic effects from changes in the ozone and $\mathrm{CO}_{2}$ are likely driving observed changes in the meridional temperature gradients and of the BDC of the lower stratosphere. Based on the results of the CCM stud-

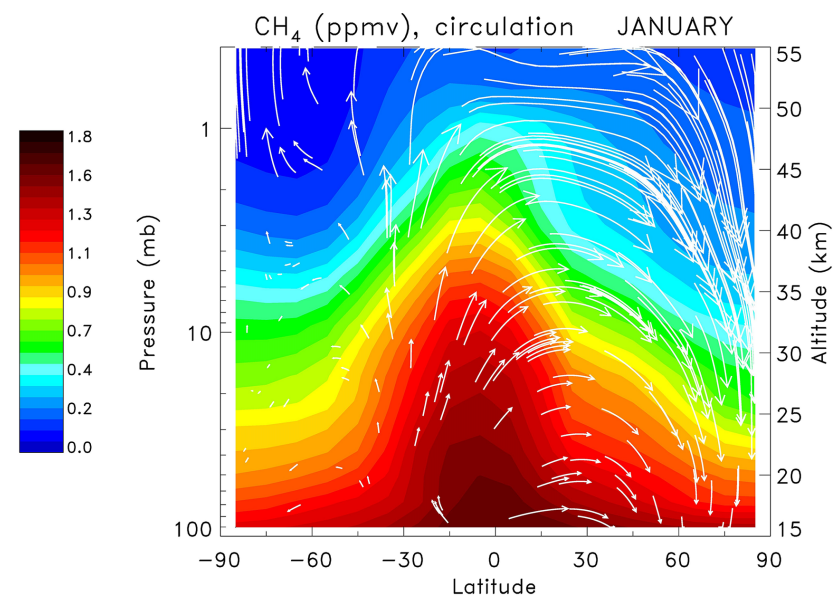

Figure 2. Methane distribution (ppmv) for January based on a chemistry and transport model simulation. White arrows indicate the sense and strength of the net circulation (image courtesy of Eric Fleming).

ies, they decomposed the BDC into a transition (100-70 hPa) branch, a shallow $(70-30 \mathrm{hPa})$ branch, and a deep $(30 \mathrm{hPa}$ and higher) branch. Further, the CCM studies predict an acceleration of the BDC that will affect the rate of recovery for the ozone layer in the lower stratosphere.

Observational evidence for the diagnosis of a long-term acceleration of the several branches of the BDC and their associated mean age-of-air (AoA) is somewhat ambiguous from time series of stratospheric temperatures (Butchart, 2014). However, recently Diallo et al. (2012, Fig. 13) and Monge-Sanz et al. (2013, Fig. 3) found a decrease of mean AoA in the shallow branch and an increase of AoA in the deep branch of the BDC for the ERA-Interim time period of about 1989-2010. Alternatively, Garcia et al. (2011) recommended obtaining AoA using observed chemical tracers that are well sampled, have linear $\left(\mathrm{CO}_{2}\right)$ or exponential $\left(\mathrm{SF}_{6}\right)$ growth rates, and no chemical loss in the stratosphere. To that end, Ray et al. (2014), Stiller et al. (2012), and Ploeger et al. (2015a) have successfully employed measured profiles of $\mathrm{CO}_{2}$ and $\mathrm{SF}_{6}$ to diagnose trends in the AoA or the BDC and to separate the effects of the residual circulation from the effects of mixing processes. Their analyses apply to pressure altitudes or potential temperatures of the lower stratosphere $(16$ to $30 \mathrm{~km})$. What about other chemical tracers? For example, hydrogen fluoride (HF) is a stratospheric end product of the photochemical conversion from chlorofluorocarbon (CFC) molecules but has been increasing non-linearly, so it is not a good candidate for such studies. $\mathrm{H}_{2} \mathrm{O}$ has shown longterm increases of about $0.6 \% \mathrm{yr}^{-1}$ (Scherer et al., 2008), but $\mathrm{H}_{2} \mathrm{O}$ entering the stratosphere from below is subject to seasonal and occasional episodic changes of the temperature at the tropical tropopause. On the other hand, $\mathrm{CH}_{4}$ exhibits a small, monotonic, and nearly linear, annually averaged trend in the troposphere (see Sect. 5 for more details), and $\mathrm{CH}_{4}$ is 
unaffected during its upward transport through the tropical tropopause.

Generally, it is not possible to diagnose AoA or an acceleration of the BDC solely from a time series of a chemical tracer like $\mathrm{CH}_{4}$ because its mixing ratio, $\chi(r, t)$, at a specific location $r$ in the stratosphere is the integral of the product in expression (1) below for all past times $t^{\prime}$ from $-\infty$ to $t$, where $\chi_{o}\left(t^{\prime}\right)$ is the time series for $\mathrm{CH}_{4}$ in the troposphere, $G\left(r, t^{\prime}\right)$ is the stratospheric age spectra or transit time distribution (its first moment being the mean AoA), and $L\left(r, t^{\prime}\right)$ is its loss function that depends on the path spectra and the chemical sink distribution for $\mathrm{CH}_{4}$ in the stratosphere (Volk et al., 1997).

$\chi_{o}\left(t^{\prime}\right) G\left(r, t^{\prime}\right) L\left(r, t^{\prime}\right)$

The source function, $\chi_{o}\left(t^{\prime}\right)$, is estimated to have a trend of about $3 \%$ decade $^{-1}$ from 1990 to 2003, as discussed later in Sect. 5. The loss function at a given stratospheric location, $L\left(r, t^{\prime}\right)$, is related to the decay of the tracer along the complete path spectrum (all pathways from the entrance region, or tropical tropopause, to the specific location), and only tracers with constant tropospheric values and of a radioactive decaying type within the stratosphere are truly path independent (Hall and Plumb, 1994). Even if the time series for the $\mathrm{CH}_{4}$ source gas is approximately linear, it should be clear from Fig. 2 that $L\left(r, t^{\prime}\right)$ is spatially inhomogeneous in both the vertical and meridional directions. One cannot easily sort out the components of changes in the mean AoA from changes in the path spectra (Schoeberl et al., 2000). However, to first approximation, both the path and loss function $L$ can be assumed stationary, such that $\mathrm{CH}_{4}$ in the stratosphere is a fraction $(f)$ of the tropospheric $\mathrm{CH}_{4}$ and where $\mathrm{f}$ is a function of latitude/height and season (e.g., Fueglistaler, 2012). Deviations from this scenario are interpreted in the present study as being indicative of changes in the age spectra $G$, rather than $L$. This approximation follows from the idea that the chemical effects of changes in stratospheric composition for the methane oxidation rates are small. The tropospheric trends for the $\mathrm{CH}_{4}$ source gas are small, and the annually averaged, chemical loss term for $\mathrm{CH}_{4}$ in the stratosphere should give rise to spatial gradients that are very nearly symmetric across the two hemispheres. Despite those considerations for hemispheric symmetry, the analyses of time series of observed stratospheric $\mathrm{CH}_{4}$ show that their long-term trends differ between the Northern Hemisphere and the Southern Hemisphere and indicate significant changes from the effects of mixing on the BDC in the middle stratosphere of each hemisphere.

\section{Objectives}

The modeled $\mathrm{CH}_{4}$ distribution in Fig. 2 is very similar to observed wintertime distributions of $\mathrm{CH}_{4}$ from satellite data sets. $\mathrm{CH}_{4}$ is decreasing with pressure altitude and with lat- itude because $\mathrm{CH}_{4}$ is oxidized in a multi-step process to $\mathrm{H}_{2} \mathrm{O}$ in the middle and upper stratosphere (e.g., Brasseur and Solomon, 2005). In an early study using $\mathrm{CH}_{4}$ data from the Stratospheric and Mesospheric Sounder (SAMS) on Nimbus 7, Stanford and Ziemke (1991) determined empirically that the minimum lifetime for its chemical conversion to $\mathrm{H}_{2} \mathrm{O}$ is of the order of 3 to 4 months at low latitudes in the upper stratosphere or somewhat longer than the time constants for the mean meridional transport. Holton and Choi (1988) and Stanford et al. (1993) used the 3 years of SAMS $\mathrm{CH}_{4}$ data as a tracer for the characterization of the vertical and meridional components of the seasonal net transport. The present analysis study makes use of time series of $\mathrm{CH}_{4}$ mixing ratio data as a function of pressure altitude for 1992-2005 from the Halogen Occultation Experiment (HALOE) aboard the Upper Atmosphere Research Satellite (UARS). As noted by Rosenlof (2002) and by Neu et al. (2003), atmospheric sampling via the method of solar occultation is adequate typically for obtaining the large-scale seasonal variations of $\mathrm{CH}_{4}$.

The HALOE instrument obtained sunrise (SR) and sunset (SS) profiles of $\mathrm{CH}_{4}$ in the stratosphere and lower mesosphere, and a number of researchers have made use of its $\mathrm{CH}_{4}$ data for studies of middle atmosphere transport. Ruth et al. (1997), Randel et al. (1998, 1999), Gray and Russell III (1999), and later Shu et al. (2013) used the multi-year distributions of the $\mathrm{HALOE} \mathrm{CH}_{4}$ mixing ratio as a tracer for the effects of the semi-annual oscillation (SAO) and quasibiennial oscillation (QBO) forcings. Youn et al. (2006) analyzed time series of $\mathrm{CH}_{4}, \mathrm{H}_{2} \mathrm{O}$, and $\mathrm{HF}$ from HALOE for their trends at $10 \mathrm{hPa}$ and in one latitude zone, 40 to $45 \mathrm{de}$ grees, and they found differences in their trends between the two hemispheres. They related the trends that they found for the Northern Hemisphere to an intensification of stratospheric wave activity over that 14-year time span.

The present study is an analysis of time series of the $\mathrm{HALOE} \mathrm{CH}_{4}$ for an increasing (positive) trend in the tropical ascent and for a correspondingly increasing (negative) trend in the extratropical descent in the same hemisphere. Multiple linear regression (MLR) techniques are used for the analyses and are discussed in Sect. 3, and they fit the seasonal and the interannually varying forcings along with the trend terms in time series of $\mathrm{CH}_{4}$ as a function of latitude and pressure altitude. Preliminary MLR model results are also shown in Sect. 3, and concerns about having an adequate number of profile samples for each of the SR and SS crossings of a latitude zone are addressed in Sect. 4. Final sets of $\mathrm{CH}_{4}$ time series are selected as representative of the tropical and extratropical latitude zones of each hemisphere, as depicted in the simple schematic of Plumb (2007, his Fig. 13). An estimate of the trends for the $\mathrm{CH}_{4}$ source gas is presented in Sect. 5. Then the coefficients of the stratospheric trend terms from HALOE and their statistical significance are given and compared with that of the source gas for each latitude zone and as a function of pressure altitude. Trends from the study herein are compared with those reported by other groups, which in 
some instances were based only on HALOE data through the 1990s.

Trends from analyses of HALOE $\mathrm{H}_{2} \mathrm{O}$ are shown in Sect. 6 and compared with those of $\mathrm{CH}_{4}$ for consistency, since $\mathrm{H}_{2} \mathrm{O}$ is the primary chemical product of $\mathrm{CH}_{4}$ oxidation at the upper altitudes. Section 6 also relates the time series of residuals from analyses of $\mathrm{CH}_{4}$ in the lower mesosphere to deseasonalized variations in $\mathrm{HCl}$, another molecule that contains information about the BDC of the stratosphere and mesosphere. In particular, it is shown that the residuals from the separate MLR fits to the $\mathrm{CH}_{4}$ and $\mathrm{HCl}$ series have small, irregular variations of opposite sign. It is posited that the somewhat anomalous variations in the multi-year time series of $\mathrm{HALOE} \mathrm{HCl}$ for the lower mesosphere that have been reported by others are due to effects from anomalous wave forcings during 1999-2002. Section 7 is a summary of findings from the present analyses.

\section{Analysis approach}

Effects from the seasonal BDC are apparent from monthly, zonal-mean cross sections of $\mathrm{CH}_{4}$, as shown by Holton and Choi (1988) from the SAMS data and by Randel et al. (1998) and Shu et al. (2013) from the HALOE data. Qualitatively, there is a net upward transport of $\mathrm{CH}_{4}$ at the low latitudes, a net poleward transport throughout the stratosphere, plus a descent of $\mathrm{CH}_{4}$-poor air within the polar vortex beginning at upper altitudes (cf. Fig. 2). The monthly $\mathrm{CH}_{4}$ distributions also exhibit a significant, negative mixing ratio gradient from the tropics to higher latitudes along pressure surfaces in the middle and upper stratosphere. The exact latitude location of the maximum gradient varies seasonally, according to the strength of the meridional mixing of the air masses that occurred in the weeks before. Latitude versus pressurealtitude cross sections of the $\mathrm{CH}_{4}$ from the HALOE Website (http://haloe.gats-inc.com/home/) for October of successive years reveal that the isolines of the tropical $\mathrm{CH}_{4}$ distribution did not extend into the upper stratosphere during 1991, 1993, 1995, 1997, 1999, and 2004, while they were elevated in 1992, 1994, 1998, 2002, and 2003. $\mathrm{CH}_{4}$ variations for 1996, 2000, and 2001 were intermediate to those of the other years. Gray and Russell III (1999) and Shu et al. (2013) showed that the apparent, interannual strength or upward extent of the $\mathrm{CH}_{4}$ due to the mean meridional circulation is related to the phase of the QBO and/or to the effects of the Rossby-wave forcing. To first order, the isolines of the $\mathrm{CH}_{4}$ in Fig. 2 and in the HALOE data also indicate that there are distinct BDC branches in the Northern Hemisphere and in the Southern Hemisphere.

Points for the data time series of the present study are generated using the HALOE version 19 , Level $2 \mathrm{CH}_{4}$ profiles from occurrences of the HALOE SR or SS observations within a latitude zone for 1992-2005, as in Remsberg (2008). The SR and SS profiles are binned into 14 overlapping lati-
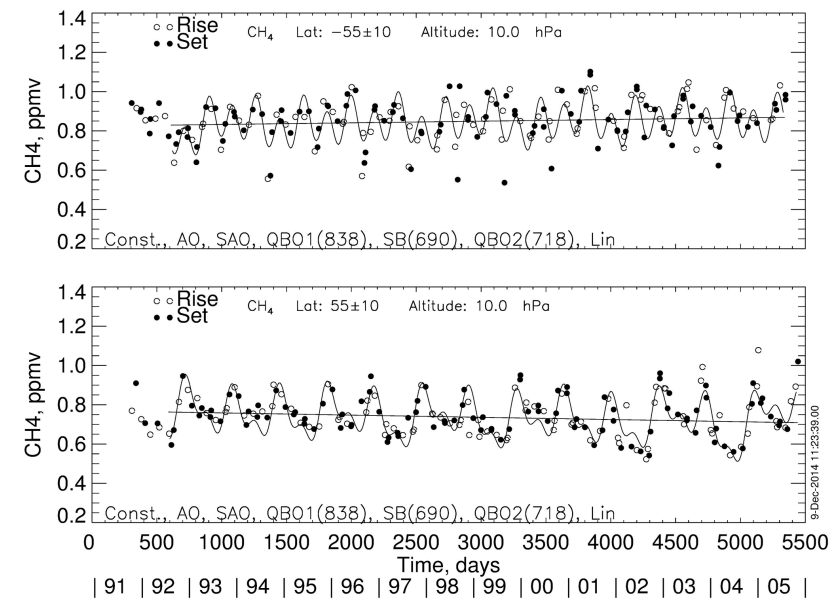

Figure 3. Time series of $\mathrm{CH}_{4}$ is from HALOE at $10 \mathrm{hPa}$ and at $55^{\circ}$ latitude for the (top) Southern Hemisphere and for the (bottom) Northern Hemisphere. Solid and open circles indicate the binaveraged $\mathrm{CH}_{4}$ data for sunset and sunrise, respectively. The oscillating curve is the MLR fit to the data based on the terms indicated at the lower left, and the near-horizontal line represents the sum of the constant and linear trend terms.

tude zones from $65^{\circ} \mathrm{S}$ to $65^{\circ} \mathrm{N}$ and at 12 pressure altitudes, giving a total of 168 separate time series for analysis. Initially, the width of each latitude bin was set to $20^{\circ}$, ensuring a relatively large number of samples. Example time series for the southern and northern extratropics are shown in Fig. 3 at $10 \mathrm{hPa}$ (near $31 \mathrm{~km}$ ). Each data point in Fig. 3 is an approximate snapshot of the zonally averaged $\mathrm{CH}_{4}$ for the latitude zone (cf. Fig. 2). The oscillating curves in Fig. 3 are the MLR fits to the data points from mid-1992 onward and based on the terms indicated at the lower left of the figure. The near horizontal line is the sum of the constant and linear trend terms of the MLR model.

Results of similar MLR analyses of time series of HALOE data were reported for ozone (Remsberg, 2008), temperature (Remsberg, 2009), and mesospheric water vapor (Remsberg, 2010). Details of the formulation of the terms for the MLR models can be found in Remsberg (2008) and are summarized here. Initially, only semiannual (SAO) and annual (AO) terms are considered for the model. A Fourier analysis is then applied to the residual or difference of the model values from the points in the time series, in order to identify significant periodic, interannual terms that remain. Three interannual terms are almost always present and are included in the model: an 838-day (27.5-month) or QBO1 term; a small amplitude, 718-day (23.5-month) biennial or QBO2 term; and a 690-day (22.6-month) sub-biennial (SB) term, whose period arises from the difference interaction between QBO and annual terms. The relative amplitudes of these three interannual terms vary with latitude and altitude (see also Baldwin and Dunkerton, 1998). The 22.6-month term agrees closely with the anti-symmetric empirical orthogonal 
function (EOF) identified by Dunkerton (2001, his Eq. 5.2) for the subtropical latitudes from a shorter series of HALOE $\mathrm{CH}_{4}$ data. The primary purpose of identifying and including interannual terms in the MLR model is so that their significant structures can be accounted for. A linear trend term is also part of the final models. Lag-1 autocorrelation (AR-1) effects are a significant part of the MLR models for zonally averaged stratospheric data. The accounting for AR-1 effects corrects for minor, but important biases between the MLR model and the $\mathrm{CH}_{4}$ points that often occur along short segments of the data series. Corrections for AR-1 effects follow the two-step approach of Tiao et al. (1990, their Appendix A), and those corrections have a significant impact on the analyzed trend terms.

Data in the first year following the Mt. Pinatubo eruption of June 1991 often appear to have been perturbed, so that time span is not considered for the MLR fittings. In Fig. 3 (bottom) one can see that there is also a weak, decadal-scale variation in the data series, whose amplitude is characterized by a difference interaction between the QBO1 and SB terms (or near to the 10.6-year period found by Baldwin and Dunkerton, 1998). However, a separate term with that period is not part of the MLR models of the present study. In addition, Nedoluha et al. (1998) reported that solar cycle (SC) effects on $\mathrm{CH}_{4}$ are very small even near the stratopause; thus, no 11-year or SC-proxy term is included in the MLR models. However, there is a cooling of the middle atmosphere during this 14-year time span, due to the increasing atmospheric $\mathrm{CO}_{2}$. Therefore, the analyses are conducted for time series of the $\mathrm{CH}_{4}$ mixing ratio at pressure altitudes rather than geometric altitudes. In this way, the added effects from the contraction of a pressure surface with altitude and time are avoided. It is further assumed that the age spectrum $G$ is invariant in pressure space if the dynamical forcing is invariant in pressure space. To first order then, the variations of $\mathrm{CH}_{4}$ with time at a pressure level represent the effects of the diabatic transport vertically within a zone and any horizontal mixing to/from adjacent latitude regions.

Figure 3 depicts the $\mathrm{CH}_{4}$ time series for $10 \mathrm{hPa}$ and at $55^{\circ}$ latitude for the two hemispheres. Figure 4 shows the associated, annual mean distribution of $\mathrm{CH}_{4}$ that is based on the constant terms from the MLR models, and the mean mixing ratios for $10 \mathrm{hPa}$ are nearly the same or $0.77 \mathrm{ppmv}$ at $55^{\circ} \mathrm{N}$ and $0.82 \mathrm{ppmv}$ at $55^{\circ} \mathrm{S}$. The amplitudes of the SAO and the AO terms in Fig. 3 are more distinct in the Southern Hemisphere than in the Northern Hemisphere, despite the fact that the seasonal cycle for the mean meridional circulation of each hemisphere is mainly just a consequence of similar variations in the dynamical forcing between Equator and pole. Figure 3 (bottom) shows that the seasonal maximum occurs in late autumn to early winter in the northern extratropics, and its minimum is in late summer. It may be that the $\mathrm{SAO}$ and $\mathrm{AO}$ cycles at $55^{\circ} \mathrm{N}$ are influenced and the annual mean mixing ratio reduced slightly, due to meridional mixing of the air during late winter to spring. On the other

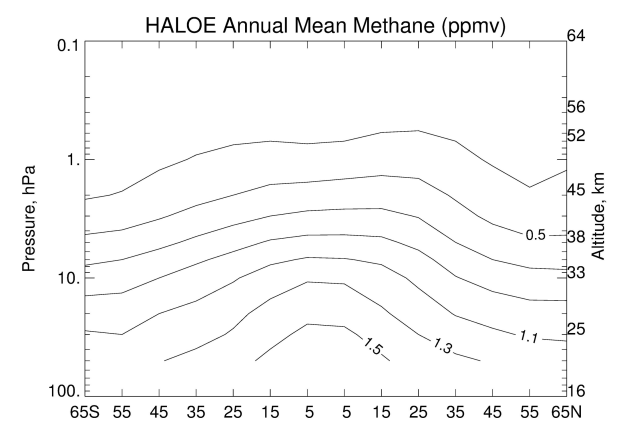

Figure 4. Annually averaged, zonal mean HALOE methane from the MLR analyses (contour interval is $0.2 \mathrm{ppmv}$ ).

hand, Fig. 3 (top) at $55^{\circ} \mathrm{S}$ shows minimum data values of 0.5 to $0.6 \mathrm{ppmv}$ for some years and most often in late winter, and they are not fit well by the MLR model. That circumstance is because those perturbations in the $\mathrm{CH}_{4}$ data occur for only a short time (few weeks) in late winter/early spring, or at the time of the final warming in the Southern Hemisphere; those rapid variations are not resolved by the terms of the MLR model. The amplitudes of the several interannual terms are also significant in the extratropics at $10 \mathrm{hPa}$. Finally, the trend coefficients from the data of Fig. 3 are slightly positive in the south but negative in the north; that difference is discussed further in Sect. 5.

Corresponding $\mathrm{CH}_{4}$ time series at $7 \mathrm{hPa}$ are shown for the two subtropical zones in Fig. 5. Periodic variations in Fig. 5 (top) for the Southern Hemisphere are primarily from the annual and QBO cycles; its average $\mathrm{CH}_{4}$ is about $1.1 \mathrm{ppmv}$. Effects from the SAO term do not emerge clearly until the upper stratosphere (not shown). The data for the northern subtropics in Fig. 5 (bottom) indicate a seasonal cycle that is more variable and somewhat weaker than in the south; interannual effects (QBO and SB) are present but are weaker, too. In general, there is less periodic structure in the $\mathrm{CH}_{4}$ of the northern subtropics at this level, again most likely because of the mixing effects from the dissipation of Rossby waves and gravity waves. Mixing of air from the middle latitudes may explain its occasional, low wintertime data values (e.g., Ploeger et al., 2015a). The trend coefficients are positive for the subtropics of both hemispheres. At this point it is also noted that changes in the BDC based on the $\mathrm{CH}_{4}$ variations in the southern subtropics can also be affected by the stronger, extratropical wave forcings of the Northern Hemisphere (see also Sect. 6).

Estimates of the trends for $\mathrm{CH}_{4}$ in terms of latitude versus pressure altitude are shown in Fig. 6. The HALOE $\mathrm{CH}_{4}$ profiles for this plot are averaged for each of the 12 pressure altitudes from 0.4 to $50 \mathrm{hPa}$ and within 14 overlapping, $20^{\circ}$-wide latitude bins centered from $65^{\circ} \mathrm{S}$ to $65^{\circ} \mathrm{N}$. Trend contours are drawn at intervals of $4 \% \mathrm{decade}^{-1}$; the solid contours are positive, while the dashed contours are negative. Positive trends occur at low to middle latitudes and are inter- 

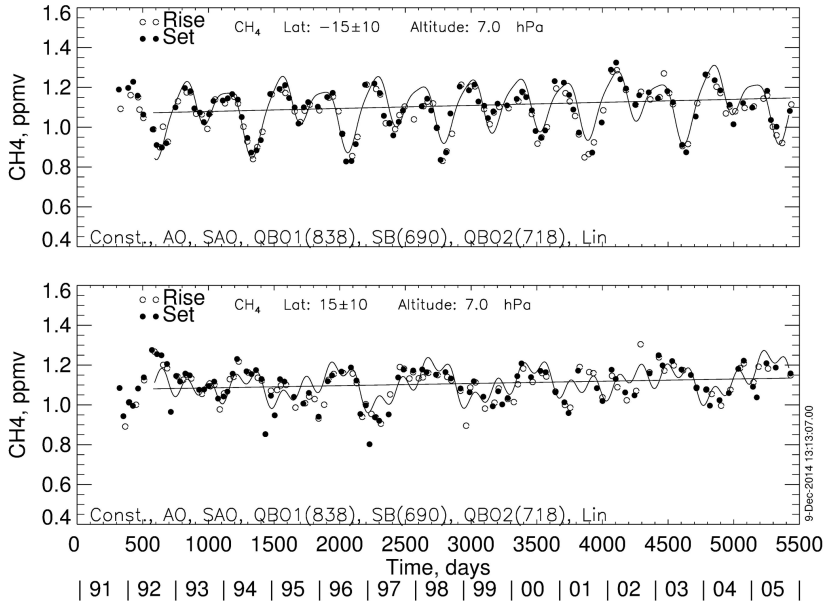

Figure 5. As in Fig. 3, but at $7 \mathrm{hPa}$ and at $15^{\circ}$ latitude for the (top) Southern Hemisphere and for the (bottom) Northern Hemisphere.

preted as indicating an upward acceleration for the tropical branch of the BDC plus an acceleration poleward. The negative trends or dashed contours at the high latitudes indicate the downward acceleration of the polar branch of the BDC within each hemisphere. Dark shading in Fig. 6 is where the trend term from the MLR model is present with greater than $90 \%$ confidence; lighter shading denotes where that confidence is between 70 and $90 \%$. The trend profiles at most latitudes from $50 \mathrm{hPa}$ to about $5 \mathrm{hPa}$ are significant and display a coherent character for an acceleration of an Equator-to-pole or BDC circulation within each hemisphere, at least during the period of the HALOE measurements. The trends from $50 \mathrm{hPa}$ to about $10 \mathrm{hPa}$ are also clearly asymmetric or positive in the Northern Hemisphere to near zero in the Southern Hemisphere. However, the trends in the tropics are of the order of $3 \%$ decade $^{-1}$ or equivalent to that expected from the tropospheric source gas (see also Sect. 5).

\section{Data sampling and data bias concerns}

Figure 6 shows that there are rather sharp meridional gradients in the $\mathrm{CH}_{4}$ trends of the upper stratosphere at $35^{\circ} \mathrm{N}$, but not at $35^{\circ} \mathrm{S}$. The middle latitudes are where there is often a strong negative meridional gradient in the isolines of $\mathrm{CH}_{4}$ (cf. Fig. 2), but the MLR models herein do not have a term to account for a variation with latitude. Rosenlof (2002, her Fig. 4) did not find a similar strong gradient in the trends from her analyses of HALOE profiles, but then she only analyzed data for 1992-2001. A more important difference is that she averaged the HALOE profiles within latitude bins of width $5^{\circ}$, rather than $20^{\circ}$. A narrower bin width is clearly preferred, but there can be a problem with having fewer profiles for the latitude bin. This concern is explored as follows. First, it is noted that major advantages of solar occultation measurements are the high signal-to-noise ratios for their limb

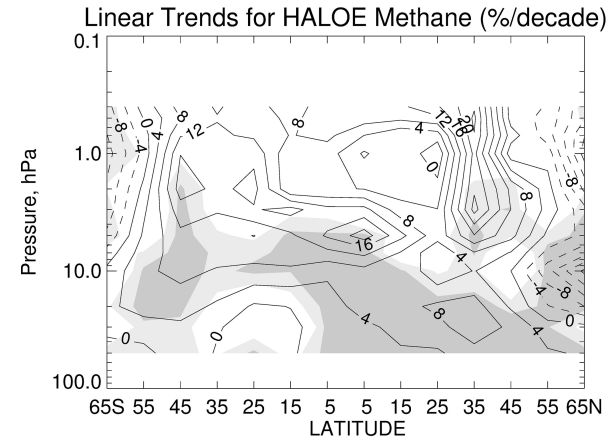

Figure 6. Linear trends for HALOE methane (in $\%$ decade $^{-1}$ ). Zero and positive trends are solid contours and negative trends are dashed; contour interval is $4 \%$ decade $^{-1}$. Dark shading denotes where the trends have a confidence interval $(\mathrm{CI}) \geq 90 \%$, and lighter shading denotes $70 \% \leq \mathrm{CI} \leq 90 \%$.

transmission profiles and their inherently good vertical resolution; each retrieved HALOE $\mathrm{CH}_{4}$ profile is quite accurate and has a vertical resolution of about $4 \mathrm{~km}$ (Park et al., 1996). Still, for the lower latitudes HALOE typically made its measurements across a given latitude bin over just a few days, due to the alternating nature of the time sequence of its SR and SS occultations from the UARS satellite. Rosenlof (2002) combined the SR and SS measurements within $5^{\circ}$ bins and calculated their monthly averages. However, in the present study the SR and SS profiles are averaged separately. In addition, the exact latitude crossing times for their averages are retained, in order to yield better fits for the AO and especially the SAO terms of the MLR model. Zonal variations for $\mathrm{CH}_{4}$ occur normally at low wavenumber and with small amplitudes compared with its zonal mean value. Thus, a minimum of five profiles is required for the separate SR or SS bin averages; that number is judged as representative of the true zonal mean, where the separation between profiles from successive orbits is about $24^{\circ}$ longitude. As a check, it was found that requiring a minimum of seven profiles gave time series having slightly fewer data points, but their analyzed trends were essentially unchanged from before. An exception is at high latitudes during dynamically active winters, but those occurrences are rather short and infrequent across the 14-year time series of the HALOE measurements.

To have separate SR and SS samples that are representative of zonal mean $\mathrm{CH}_{4}$, a bin width of $10^{\circ}$ is considered instead for the data points of the time series, and new MLR analyses are carried out. Table 1 compares the resulting trend profiles using bin widths of $10^{\circ}$ vs. $20^{\circ}$ for three selected latitudes of the Northern Hemisphere. The trend terms that are highly significant are in bold, i.e., having a confidence interval (CI) of being present in the time series that is greater than or equal to $95 \%$. Where the corresponding trends are significant at a given latitude, they are not changed by much using the narrower bins. However, for the upper stratosphere of Table 1 
Table 1. Methane trend profiles $\left(\%\right.$ decade $\left.^{-1}\right)$. Bold denotes trend terms having confidence intervals $(\mathrm{CI}) \geq 95 \%$.

\begin{tabular}{rrrrrrr}
\hline$P$ & $10^{\circ} \mathrm{N}$ & $10^{\circ} \mathrm{N}$ & $35^{\circ} \mathrm{N}$ \\
\pm 10 & $\begin{array}{r}35^{\circ} \mathrm{N} \\
\pm 5\end{array}$ & $\begin{array}{r}60^{\circ} \mathrm{N} \\
\pm 10\end{array}$ & $\begin{array}{r}60^{\circ} \mathrm{N} \\
\pm 5\end{array}$ \\
\hline 0.4 & 10.2 & 7.7 & 23.5 & 12.3 & -8.5 & -29.6 \\
0.5 & 9.6 & 8.7 & 24.9 & 8.6 & -10.7 & -25.2 \\
0.7 & 3.1 & 1.5 & 23.8 & 4.5 & -17.8 & -28.0 \\
1.0 & -0.6 & -4.2 & 21.3 & 2.0 & -19.0 & -22.5 \\
2.0 & 5.1 & 1.2 & 23.4 & 7.8 & $-\mathbf{1 0 . 3}$ & -3.7 \\
3.0 & 8.2 & 8.7 & 25.4 & 15.5 & -7.2 & -3.3 \\
5.0 & 16.3 & 20.4 & $\mathbf{1 5 . 7}$ & 13.8 & $\mathbf{- 8 . 3}$ & $\mathbf{- 6 . 3}$ \\
7.0 & $\mathbf{1 1 . 5}$ & $\mathbf{1 2 . 2}$ & 7.7 & 7.0 & $\mathbf{- 1 4 . 2}$ & $\mathbf{- 1 1 . 3}$ \\
10.0 & $\mathbf{7 . 4}$ & $\mathbf{9 . 8}$ & 4.2 & 1.3 & $\mathbf{- 2 1 . 3}$ & $\mathbf{- 1 9 . 5}$ \\
20.0 & $\mathbf{8 . 0}$ & $\mathbf{1 0 . 0}$ & $\mathbf{9 . 7}$ & $\mathbf{5 . 7}$ & $\mathbf{- 6 . 7}$ & $\mathbf{- 8 . 4}$ \\
30.0 & $\mathbf{4 . 3}$ & $\mathbf{3 . 8}$ & $\mathbf{1 0 . 7}$ & $\mathbf{8 . 6}$ & 0.9 & 0.3 \\
50.0 & $\mathbf{3 . 4}$ & $\mathbf{3 . 3}$ & $\mathbf{6 . 5}$ & $\mathbf{6 . 2}$ & $\mathbf{3 . 4}$ & 3.8 \\
\hline
\end{tabular}

at $35^{\circ} \mathrm{N}$, the trends are smaller now compared with those found in Fig. 6 using the wider bins. Though not highly significant, those changes are the result of including measured profiles that are more nearly representative of the exact latitude zone of $35^{\circ} \mathrm{N}$. The previously large positive trends in the upper stratosphere in Fig. 6 may imply that the location of a given isoline of $\mathrm{CH}_{4}$ moves poleward due to changes in the wave activity and mixing. No similar change is evident for the middle latitudes of the Southern Hemisphere. An analysis of trends in the transport from an assimilation model is required to really interpret those changes at $35^{\circ}$ latitude because the present results from $\mathrm{HALOE} \mathrm{CH}_{4}$ are truly due to the combined effects of the stratospheric age spectra, $G$, and the loss function, $L$. The remainder of the paper focuses on trend results obtained from profiles in selected bins of $10^{\circ}$ in width.

Changes in the HALOE instrument have been evaluated in terms of any potential errors for the trends in the data over its 14-year time series (Gordley et al., 2009). They found that there was a change in the $\mathrm{CH}_{4}$ gas cell concentration, leading to a false trend in its $\mathrm{CH}_{4}$ mixing ratio of $-1.9 \pm 0.7(1 \sigma) \%$ decade $^{-1}$ that is constant with pressure altitude. A first order correction for that false trend would be to add $1.9 \%$ decade $^{-1}$ to the analyzed trends, although that correction is not applied to the final results herein because it is not obtained strictly through the MLR fit process. A separate concern relates to the pressure profiles associated with the HALOE Level $2 \mathrm{CH}_{4}$ transmission signals. Specifically, an initial registration for the retrieval uses the temperature versus pressure or $T(p)$ values at $31.5 \mathrm{~km}$ altitude from operational data that were supplied to the UARS Project in near real time by the NOAA Climate Prediction Center (CPC) (Thompson and Gordley, 2009). The Level 2 retrieval algorithm for $T(p)$ also uses transmission measurements from the HALOE $\mathrm{CO}_{2}$ channel that are accurate for the upper stratosphere and mesosphere. There is a weighted merger of the HALOE retrieved $T(p)$ with the CPC profiles over the altitude range of 31.5 to $45 \mathrm{~km}$, such that the final Level $2 T(p)$ profiles are principally those from the measurements of HALOE down to about the $4 \mathrm{hPa}$ level. Remsberg and Deaver (2005, their Fig. 4) found a discontinuity near May 2001 in the HALOE $T(p)$ times series at $10^{\circ} \mathrm{N}$ at $5 \mathrm{hPa}$ (near $36 \mathrm{~km}$ ) but not at $3 \mathrm{hPa}$, and that shift is traceable to a change in the operational temperatures at that time. However, the retrieved $\mathrm{CH}_{4}$ mixing ratio versus pressure profiles are in hydrostatic balance. No similar discontinuity is indicated in the time series of the $\mathrm{HALOE} \mathrm{CH}_{4}$ at $10 \mathrm{hPa}$ (Fig. 3), at $7 \mathrm{hPa}$ (Fig. 5), or at the other analyzed levels (not shown).

\section{Trends in $\mathrm{CH}_{4}$ from the troposphere and in the stratosphere}

It is important to have a good estimate of the trends for the source term, $\chi_{o}$, so that its effects can be separated from the product of expression (1), at least to first order. Because there is about a 1-year delay for the surface methane source gas to reach the tropical middle stratosphere, a time frame of 1991-2004 is considered for the time series of the source gas. Methane from remote boundary layer sites was globally averaged by Dlugokencky et al. (2001, 2009). They showed that the de-seasonalized $\mathrm{CH}_{4}$ mixing ratios continued to grow during this period, although at rates that were slower from 1992 to 1999 (3.0\% decade ${ }^{-1}$ ) and from 1999 to 2005 (near zero) than from 1983 to 1992 ( $4.7 \%$ decade $\left.^{-1}\right)$. Exceptions were the episodic increases at the surface in 1991 and 1998 that were followed by equally sharp decreases a year later. An overall trend of $3.0 \pm 0.7 \%$ decade $^{-1}$ is obtained by considering the endpoint values at 1991 and 2004 from their globally averaged data time series. At the high latitudes, the overall trend may be slightly larger because the AoA is older there. Globally averaged, $1 \sigma$ uncertainties from the station data are of the order of $0.6 \mathrm{ppbv} \mathrm{yr}^{-1}$, giving the $2 \sigma$ value of $0.7 \%$ decade $^{-1}$ for the overall trend estimate.

A separate indication of trends from the $\mathrm{CH}_{4}$ source term to the stratosphere is obtained for the tropics from the MLR analyses of the HALOE data. Specifically, Fig. 7 shows $\mathrm{CH}_{4}$ time series at $50 \mathrm{hPa}$ for $5^{\circ} \mathrm{S}$ and $5^{\circ} \mathrm{N}$ that are part of the trend results in Fig. 6. Their linear trends and $2 \sigma$ uncertainties are $2.8 \pm 2.8$ and $3.3 \pm 3.4 \%$ decade $^{-1}$, respectively, or essentially the same values as from the tropospheric time series, although the tropospheric data have a much smaller uncertainty. The two tropical time series in Fig. 7 have a maximum in late 1992 and a somewhat non-linear (quadratic) character thereafter with a second maximum in 1999. Both maximums follow the observed episodic increases in the troposphere by about a year. The average HALOE trends and $2 \sigma$ values are $1.7 \pm 2.1$ and $3.1 \pm 2.1 \%$ decade $^{-1}$ at $30 \mathrm{hPa}$ for $5^{\circ} \mathrm{S}$ and $5^{\circ} \mathrm{N}$ from Fig. 6; however, the data time series at $30 \mathrm{hPa}$ exhibit very little to no non-linear character (not 

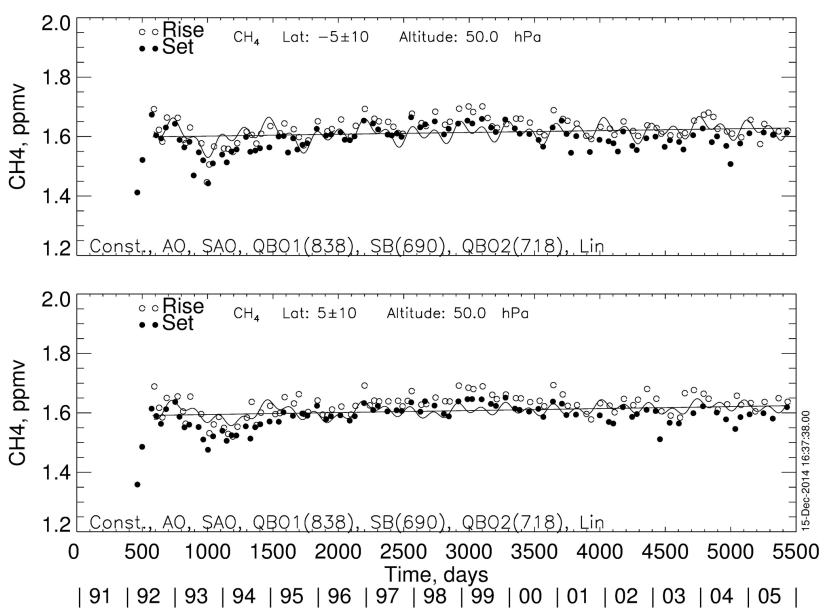

Figure 7. As in Fig. 3, but at $50 \mathrm{hPa}$ and at $5^{\circ}$ latitude for the (top) Southern Hemisphere and for the (bottom) Northern Hemisphere.

shown), and that is also the case at the other pressure altitudes.

The retrieved HALOE $\mathrm{CH}_{4}$ mixing ratios in Fig. 7 are only of order $1.4 \mathrm{ppmv}$ in early 1992 . Such low values may indicate a slight bias error at $50 \mathrm{hPa}$, due to a reduced accuracy for the measured and retrieved $\mathrm{CH}_{4}$ in the presence of the aerosol layer following the eruption of Mt. Pinatubo.

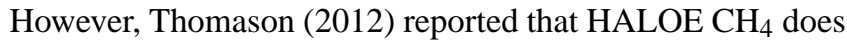
not appear to be affected by contamination from other minor or trace species within its retrieval algorithm, at least after that early volcanic period. The present study considers data points from mid-1992 and onward for the MLR analyses at all latitudes and pressure altitudes, primarily to avoid contaminating effects in the lower stratosphere and/or anomalous net transport effects at higher altitudes for some months following the eruption. There is also a small, but clear SR/SS bias in the data of Fig. 7 that is not considered real. Most likely, that bias comes about because of the temperaturepressure-height data from the NOAA CPC that are used to register the HALOE Level 2 mixing ratio profiles in the middle stratosphere. Those provisional data are for 12Z; they do not reflect the effects of the diurnal tide on height and pressure, which are significant in the tropics. No correction is applied to the separate SR and SS time series before they are combined and analyzed, however.

Time series of $\mathrm{CH}_{4}$, like those in Figs. 3 and 5, are analyzed at $60,35,10^{\circ} \mathrm{S}, 10,35$, and $60^{\circ} \mathrm{N}$, and their latitude bins have a width of $10^{\circ}$. Table 2 contains the mean $\mathrm{CH}_{4}$ mixing ratio profiles from the constant terms of the MLR models for each of the six latitude zones. The term coefficients show very good symmetry between the two hemispheres in the tropics and at the high latitudes. In the middle to lower stratosphere there is slightly more $\mathrm{CH}_{4}$ in the southern than in the northern high latitudes, indicating that the net wintertime descent is prolonged and/or a bit stronger in the north.
Table 2. Mean $\mathrm{CH}_{4}$ mixing ratio profiles (ppmv).

\begin{tabular}{rrrrrrr}
\hline$P(\mathrm{hPa})$ & $60^{\circ} \mathrm{S}$ & $35^{\circ} \mathrm{S}$ & $10^{\circ} \mathrm{S}$ & $10^{\circ} \mathrm{N}$ & $35^{\circ} \mathrm{N}$ & $60^{\circ} \mathrm{N}$ \\
\hline 0.4 & 0.20 & 0.23 & 0.23 & 0.24 & 0.24 & 0.20 \\
0.5 & 0.21 & 0.24 & 0.25 & 0.26 & 0.26 & 0.20 \\
0.7 & 0.22 & 0.28 & 0.29 & 0.31 & 0.30 & 0.22 \\
1.0 & 0.23 & 0.31 & 0.36 & 0.40 & 0.36 & 0.26 \\
2.0 & 0.28 & 0.44 & 0.57 & 0.62 & 0.49 & 0.35 \\
3.0 & 0.37 & 0.56 & 0.73 & 0.77 & 0.56 & 0.41 \\
5.0 & 0.53 & 0.74 & 0.95 & 0.96 & 0.68 & 0.52 \\
7.0 & 0.65 & 0.86 & 1.11 & 1.11 & 0.79 & 0.63 \\
10.0 & 0.78 & 0.98 & 1.26 & 1.24 & 0.90 & 0.75 \\
20.0 & 0.98 & 1.15 & 1.45 & 1.42 & 1.09 & 0.97 \\
30.0 & 1.10 & 1.22 & 1.52 & 1.51 & 1.19 & 1.06 \\
50.0 & 1.23 & 1.35 & 1.58 & 1.56 & 1.34 & 1.21 \\
\hline
\end{tabular}

At $50 \mathrm{hPa}$, the mixing ratios are very nearly identical between the two hemispheres for the tropics (1.57 ppmv), middle latitudes (1.34 ppmv), and at high latitudes (1.22 ppmv), indicating that the tropospheric $\mathrm{CH}_{4}$ that entered the lowest part of the tropical stratosphere is being transported poleward and mixed about equally with the higher latitude air. There is also a monotonic decrease of the $\mathrm{CH}_{4}$ with altitude in each latitude zone, due to the chemical oxidation of $\mathrm{CH}_{4}$ to $\mathrm{H}_{2} \mathrm{O}$. The mean $\mathrm{CH}_{4}$ mixing ratio profiles in Table 2 represent qualitatively the effects of the seasonal BDC transport within each hemisphere.

The conceptual idea of Plumb (2007, his Figs. 13 and 15) is employed for the detection of an acceleration of the hemispheric BDC using a species like $\mathrm{CH}_{4}$, whose mixing ratio decreases with altitude as in Figs. 2 and 4. Trends from the HALOE $\mathrm{CH}_{4}$ time series are interpreted as indicating a change in the strength of the BDC, when they are positive and significantly larger than $3.0 \pm 0.7 \%$ decade $^{-1}$ in the tropics or significantly smaller or even negative at the high latitudes. Thus, an acceleration of the BDC leads to higher $\mathrm{CH}_{4}$ values in the tropics and lower values in the extratropics or a steepening of its Equator-to-pole gradient with time for a given pressure altitude. On the other hand, the effects of meridional mixing can transport extratropical air back to the subtropics and cause a net recirculation and further aging of the $\mathrm{CH}_{4}$ (Garny et al., 2014). It is not possible to quantify those separate effects based on the $\mathrm{CH}_{4}$ observations alone. The analyzed trend terms $\left(\%\right.$ decade $\left.^{-1}\right)$ and the accompanying confidence intervals or $\mathrm{CI}$ (in \%) for their presence in the time series are given in Table 3. The signs of the trend terms indicate that there is an acceleration of the overall BDC within the middle stratosphere. Note that the highly significant trends are shown by boldface type; they have a CI equal to or greater than $95 \%$ of being present in the time series. The trend coefficients are highly significant and different from the trend in $\chi_{o}$ in both the tropics and extratropics from 20 to $7 \mathrm{hPa}$ in the Northern Hemisphere but only for the tropics from 10 to $5 \mathrm{hPa}$ in the Southern Hemi- 
Table 3. Southern Hemisphere and Northern Hemisphere tropical and extratropical $\mathrm{CH}_{4}$ trend profiles $\left(\%\right.$ decade $\left.{ }^{-1}\right)$ and their associated confidence intervals (CI in \%) for the presence of the terms in the MLR models. Significant trends are in bold.

\begin{tabular}{crrrr}
\hline Pressure $(\mathrm{hPa})$ & $60 \pm 5^{\circ} \mathrm{S}, \mathrm{CI}$ & $10 \pm 5^{\circ} \mathrm{S}, \mathrm{CI}$ & $10 \pm 5^{\circ} \mathrm{N}, \mathrm{CI}$ & $60 \pm 5^{\circ} \mathrm{N}, \mathrm{CI}$ \\
\hline 0.4 & $-5.3,75$ & $8.6,5$ & $7.7,34$ & $\mathbf{- 2 9 . 6 , 9 8}$ \\
0.5 & $-7.2,72$ & $9.4,7$ & $8.7,33$ & $-25.2,93$ \\
0.7 & $-11.0,83$ & $11.0,13$ & $1.5,18$ & $-28.0,92$ \\
1.0 & $-13.3,89$ & $5.9,13$ & $-4.2,59$ & $-22.5,78$ \\
2.0 & $-6.2,60$ & $5.0,21$ & $1.2,67$ & $-3.7,22$ \\
3.0 & $-5.4,82$ & $15.4,48$ & $8.7,11$ & $-3.3,71$ \\
5.0 & $-3.7,90$ & $\mathbf{1 7 . 4 , 9 7}$ & $20.4,91$ & $\mathbf{- 6 . 3 , 9 9}$ \\
7.0 & $-0.7,57$ & $\mathbf{1 3 . 3 , 9 9}$ & $\mathbf{1 2 . 2 , 9 7}$ & $\mathbf{- 1 1 . 3 , 9 9}$ \\
10.0 & $1.0,7$ & $\mathbf{6 . 9 , 9 6}$ & $\mathbf{9 . 8 , 9 9}$ & $\mathbf{- 1 9 . 5 , 9 9}$ \\
20.0 & $4.0,69$ & $1.8,93$ & $\mathbf{1 0 . 0 , 9 9}$ & $\mathbf{- 8 . 4 , 9 7}$ \\
30.0 & $0.1,7$ & $1.5,85$ & $\mathbf{3 . 8 , 9 9}$ & $0.3,2$ \\
50.0 & $-4.1,62$ & $1.8,70$ & $\mathbf{3 . 3 , 9 9}$ & $3.8,84$ \\
\hline
\end{tabular}

sphere. It is noted that some of the relatively large trends for the $\mathrm{CH}_{4}$ time series at high latitudes of the upper stratosphere also carry fairly small uncertainties from the MLR analyses, but those trends are not considered significant because there is non-periodic structure in the time series of their residuals that has not been accounted for.

Figure 8 is a plot of the trend profiles in $\%$ decade $^{-1}$ from Table 3 for 10 and $60^{\circ} \mathrm{S}$ or within the tropical pipe region of the lower stratosphere and near the edge of the polar vortex region, respectively (Palazzi et al., 2011). Their $2 \sigma$ uncertainties are shown as horizontal bars at the tropical levels, where the results are highly significant. Those trends are $17.4(3.8)$ at $5 \mathrm{hPa}, 13.3(3.6)$ at $7 \mathrm{hPa}$, and 6.9 (3.1) at $10 \mathrm{hPa}$. The vertical dashed line represents the trend of 3.0 (0.7) $\%$ decade $^{-1}$, which is the estimate of that for the tropospheric $\mathrm{CH}_{4}$. The analyzed trend at $5 \mathrm{hPa}$ is large and positive at $10^{\circ} \mathrm{S}$ and negative at $60^{\circ} \mathrm{S}$, so at least their opposing signs are consistent with the expectation for an acceleration of the BDC. The trends at 20 and $10 \mathrm{hPa}$ are positive at both latitudes, although they are less significant at $60^{\circ} \mathrm{S}$. On the other hand, there is no evidence for a change of the shallow branch ( 70 to $30 \mathrm{hPa}$ ) of the BDC from these results. The $\mathrm{CH}_{4}$ trend terms near the stratopause are also insignificant.

Figure 9 is a plot of the trend profiles from Table 3 at 10 and $60^{\circ} \mathrm{N}$. The highly significant, northern tropical trends and their $2 \sigma$ uncertainties are $12.2(3.4)$ at $7 \mathrm{hPa}, 9.8$ (3.2) at $10 \mathrm{hPa}, 10.0(3.2)$ at $20 \mathrm{hPa}, 3.8(4.2)$ at $30 \mathrm{hPa}$, and $3.3(3.0)$ at $50 \mathrm{hPa}$. The significant trends for $60^{\circ} \mathrm{N}$ are $-6.3(20.4)$ at $5 \mathrm{hPa},-11.3(14.4)$ at $7 \mathrm{hPa},-19.5(9.0)$ at $10 \mathrm{hPa}$, and -8.4 (7.6) at $20 \mathrm{hPa}$. Note that the foregoing trends are still significant after making the first order correction of $1.9 \%$ decade $^{-1}$ for a change in the HALOE $\mathrm{CH}_{4}$ gas cell. Trends at 50 and $30 \mathrm{hPa}$ vary from 3.3 to $3.8 \%$ decade $^{-1}$ at $10^{\circ} \mathrm{N}$ and from 0.3 to $3.8 \%$ decade $^{-1}$ at $60^{\circ} \mathrm{N}$, but they carry the same sign and thus disagree with the picture of an acceleration of the hemispheric BDC. Yet, they are consistent with an average trend of $3.0 \%$ decade $^{-1}$ for the tropospheric $\mathrm{CH}_{4}$, indicating that

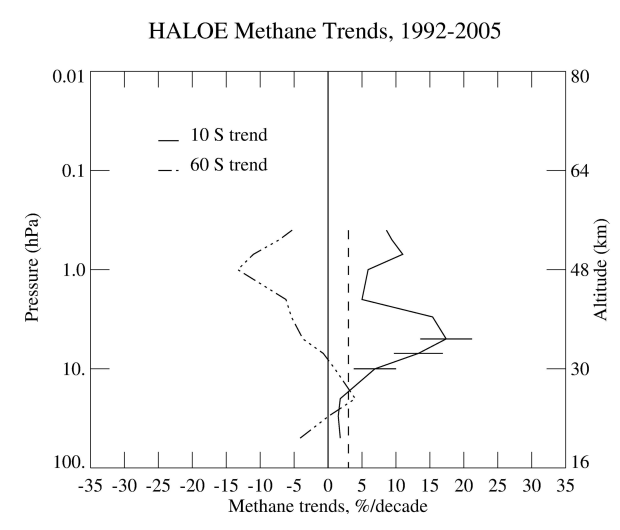

Figure 8. Tropical and high-latitude trend profiles for $\mathrm{CH}_{4}$ in the Southern Hemisphere. Vertical dashed line is the approximate trend for tropospheric $\mathrm{CH}_{4}$ or $3.0 \pm 0.7 \%$ decade $^{-1}$. Horizontal bars show the $2 \sigma$ error estimates for the highly significant trend terms.

the trends at $60^{\circ}$ latitude are merely reflecting a net transport of tropical air to the higher latitudes. The $\mathrm{CH}_{4}$ trends from 20 to $7 \mathrm{hPa}$ are larger and positive in the tropics, and the corresponding extratropical trends are increasingly negatively up to $10 \mathrm{hPa}$ and remain negative even at $5 \mathrm{hPa}$. Thus, the signs of the trends from those two northern zones imply that there was an acceleration of the BDC in the middle stratosphere during 1992 to 2005. In other words, an acceleration is indicated for the lower part of the deep branch of the BDC.

Youn et al. (2006) obtained a positive linear trend at $10 \mathrm{hPa}$ of $9 \%$ decade $^{-1}$ at $42.5^{\circ} \mathrm{S}$ and almost no trend at $42.5^{\circ} \mathrm{N}$. For comparison purposes, linear trends are calculated here for $10 \mathrm{hPa}$ and for the same narrow latitude zones of 40 to $45^{\circ}$ in each hemisphere. Those trends are $5.7 \%(6.0)$ in the Southern Hemisphere and $-4.6 \%$ (10.0) in the Northern Hemisphere. Possible reasons for the differing results may be that the MLR model of the present study incorporates a larger 


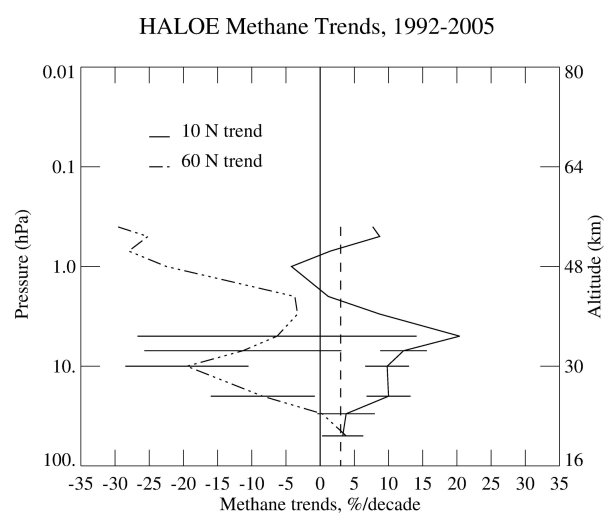

Figure 9. As in Fig. 8, but for the Northern Hemisphere.

number of periodic terms plus the effects of autocorrelation among those terms. Coincidentally though, the trends shown in Fig. 6 using the $20^{\circ}$-wide latitude bins are $9.2 \%$ (3.0) at $45^{\circ} \mathrm{S}$ and $0.0 \%(9.2)$ at $45^{\circ} \mathrm{N}$, which are almost exactly the same values reported by Youn et al. (2006).

Changes for the BDC in the upper stratosphere are difficult to detect because the photochemical lifetime for the conversion of $\mathrm{CH}_{4}$ to $\mathrm{H}_{2} \mathrm{O}$ is comparable to the time constant for the total transport. The trend in Fig. 8 at $2 \mathrm{hPa}$ is $5.0 \%$ (3.2) for $10^{\circ} \mathrm{S}$. The trend in Fig. 9 at the same level is smaller and not significant for $10^{\circ} \mathrm{N}$ or $1.2 \%$ (3.9). These findings are at odds with the rather large decreasing trends for $\mathrm{CH}_{4}$ at the lower latitudes in the upper stratosphere that were reported earlier by Nedoluha et al. (1998, their Fig. 1) for the time span of 1991-1997, by Randel et al. (1999, their Fig. 4) for 1992-1999, and even by Rosenlof (2002) for 1992-2001. An analysis of the HALOE data is carried out for the latitude zone of $10^{\circ} \mathrm{S}$ to $10^{\circ} \mathrm{N}$, but for the entire time period of $1991-$ 2005; the MLR fit to that particular time series is shown in Fig. 10. Qualitatively, the structure in the time series data compares well with that of Nedoluha et al. (1998) from late 1991 through early 1997, and separate analyses conducted here for that early period also give large negative trends. Nevertheless, those trends at $2 \mathrm{hPa}$ did not continue (Fig. 10); they are weakly positive or $3.1 \%$ decade $^{-1}$ and not significantly different from zero for the complete time series. Coincidentally though, that small trend is consistent with what is estimated from the tropospheric $\mathrm{CH}_{4}$ source gas data.

To put the analyzed trends from $\mathrm{CH}_{4}$ into context for 1992-2005, they are interpreted as follows. First, for the tropics the small positive trends in Figs. 8 and 9 for the lower stratosphere (50 and $30 \mathrm{hPa}$ ) are equivalent to the average trend of $3.0 \%$ decade $^{-1}$ for tropospheric methane; no trend in the BDC is indicated in that region. Note, however, that a correction for the estimated trend in the longterm performance of the HALOE $\mathrm{CH}_{4}$ gas cell would add about $1.9 \%$ decade $^{-1}$ to the MLR diagnosed trends herein, or somewhat larger than the average tropospheric trend. A positive trend for $\mathrm{CH}_{4}$ in this region implies a decreasing (or

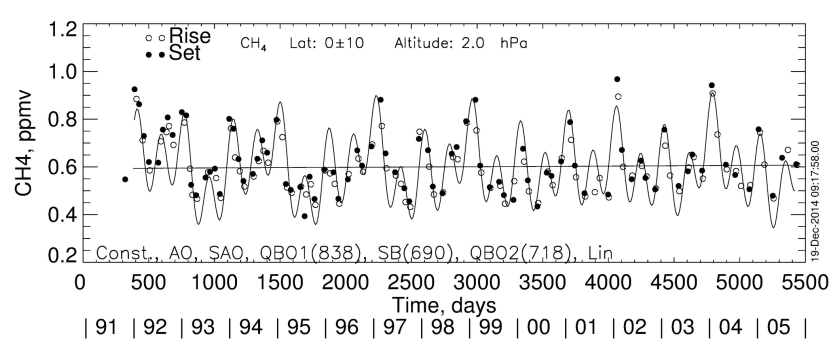

Figure 10. Time series of $\mathrm{HALOE} \mathrm{CH}_{4}$ at $2 \mathrm{hPa}$ at the tropical latitudes for comparison with that of Nedoluha et al. (1998).

younger) AoA, which is generally consistent with the AoA estimates of Diallo et al. (2012, Fig. 13) and Monge-Sanz et al. (2013, Fig. 3) from their analyzed winds and heating rates for the period of about 1990-2010. Trends in the tropical HALOE $\mathrm{CH}_{4}$ mixing ratio are increasing from 30 to $5 \mathrm{hPa}$ and imply that AoA is decreasing in that region, too. In other words, the region where the analyzed $\mathrm{CH}_{4}$ trends are greater than about $4.9 \% /$ decade corresponds to where AoA estimates ought to be decreasing. This finding differs from the AoA trends of Diallo et al. (2012) and Monge-Sanz et al. (2013), although it is in reasonable agreement with the findings of Ploeger et al. (2015b, Fig. 2) based on their analyses of AoA trends for 1990-2013. An increase in the $\mathrm{CH}_{4}$ of the mid to upper tropical stratosphere may have occurred in 1992 due to the effects of the Pinatubo aerosols (Considine et al., 2001; Al-Saadi et al., 2001). That initial acceleration of the BDC was likely followed by an extended period of negative $\mathrm{CH}_{4}$ trends, as reported by Rosenlof (2002) and Nedoluha et al. (1998). Randel et al. (1999) also reported on a rather episodic rebound for the $\mathrm{CH}_{4}$ of the lower mesosphere in 1997-1998. However, Fig. 10 indicates that the upward extension of $\mathrm{CH}_{4}$ at the $2 \mathrm{hPa}$ level at that time may have been merely due to interactions with the QBO.

For the middle latitudes the results in Fig. 6 indicate likely contributions from the effects of both horizontal transport and mixing. The trends agree broadly with the early findings of Rosenlof (2002) that were based on $\mathrm{HALOE} \mathrm{CH}_{4}$ from just 1992-2001. Positive $\mathrm{CH}_{4}$ trends in the middle stratosphere may imply a weakening of the subtropical barriers to transport out of the tropics and toward middle latitudes. This assumption agrees with the decreasing AoA reported by Ploeger et al. (2015b, Fig. 2) for the Southern Hemisphere. However, it is at odds with their findings for the Northern Hemisphere, where they found a significant increase in AoA for the period 2002-2012. It is tentatively concluded that there was a decadal change in the $\mathrm{CH}_{4}$ and the AoA trends and in the BDC for the northern middle latitudes for 19922005 versus 2002-2012, related to changes for both the mean meridional circulation and the mixing.

For the high latitudes, Fig. 6 shows negative $\mathrm{CH}_{4}$ trends at the northern latitudes near $10 \mathrm{hPa}$ that extend equatorward to $50^{\circ} \mathrm{N}$, indicating an exchange of vortex air to lower lati- 


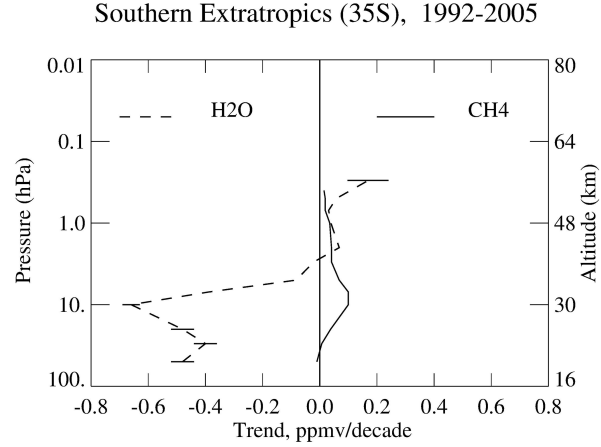

Figure 11. Trend profiles (in ppmv decade ${ }^{-1}$ ) for $\mathrm{CH}_{4}$ and $\mathrm{H}_{2} \mathrm{O}$ at $35^{\circ}$ latitude in the Southern Hemisphere. Horizontal bars denote the $2 \sigma$ uncertainties for the highly significant trends.

tudes. No equivalent net equatorward transport is apparent at $10 \mathrm{hPa}$ in the Southern Hemisphere. Finally, there are hemispheric differences in the $\mathrm{CH}_{4}$ trends of Fig. 6 for the lower stratosphere, too. In particular, the positive trends at middle latitudes of the Northern Hemisphere indicate a net poleward transport of younger, tropical air that is consistent with a decrease in the transit time for the shallow branch of the BDC (Bönisch et al., 2011). At southern high latitudes the polar vortex seems to have remained largely intact at higher altitudes. An accelerated descent of the air poleward of $65^{\circ} \mathrm{S}$ may have extended to below the $20 \mathrm{hPa}$ level, bringing older air to the lower stratosphere where it was mixed efficiently with the air at middle latitudes. Thus, the results in Fig. 6 point to distinct differences in the forcing mechanisms and for the shallow versus the deep branches of the BDC within the two hemispheres.

\section{Related trends for $\mathrm{H}_{2} \mathrm{O}$ and $\mathrm{HCl}$}

Supporting evidence is sought from the concurrent trends in HALOE $\mathrm{H}_{2} \mathrm{O}$ because $\mathrm{CH}_{4}$ is oxidized chemically to $\mathrm{H}_{2} \mathrm{O}$ in the upper stratosphere; their trends ought to be anticorrelated due to that relationship (Brasseur and Solomon, 2005; Rosenlof, 2002). The mean mixing ratio profiles for $\mathrm{H}_{2} \mathrm{O}$ are nearly symmetric for corresponding latitude zones of the two hemispheres (not shown). $\mathrm{H}_{2} \mathrm{O}$ values for the subtropics increase from about $3.9 \mathrm{ppmv}$ at $50 \mathrm{hPa}$ to about $6.3 \mathrm{ppmv}$ at $0.5 \mathrm{hPa} . \mathrm{H}_{2} \mathrm{O}$ also increases slightly from the subtropics to the extratropics in the upper stratosphere, due mostly to the oxidation of $\mathrm{CH}_{4}$ to $\mathrm{H}_{2} \mathrm{O}$ and to its subsequent transport poleward. Seasonal and interannually varying, entry-level values are found in the $\mathrm{HALOE} \mathrm{H}_{2} \mathrm{O}$ time series of the tropical lower stratosphere. There is also an episodic decrease in those entry-level values in 20002001 (Randel et al., 2006; Fueglistaler, 2012), although that change is nearly imperceptible at $10 \mathrm{hPa}$ in the time series of the middle latitudes. For the lower mesosphere it is presumed that changes are small for the remaining part of the $\mathrm{H}_{2} \mathrm{O}$ that
Northern Extratropics (35N), 1992-2005

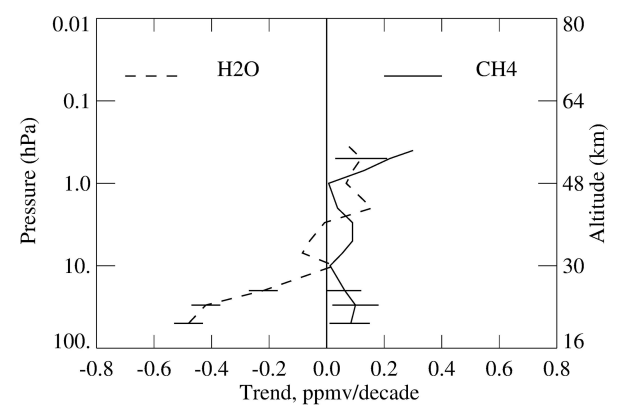

Figure 12. As in Fig. 11, but for $35^{\circ}$ latitude in the Northern Hemisphere.

is due to the variations of $\mathrm{H}_{2} \mathrm{O}$ as it enters the stratosphere through the tropical tropopause, or where the air has an average $\mathrm{H}_{2} \mathrm{O}$ mixing ratio of about $3.5 \mathrm{ppmv}$. Slightly less than half of the $\mathrm{H}_{2} \mathrm{O}$ in the lower mesosphere is from the oxidation of methane.

Trend profiles are obtained from HALOE $\mathrm{H}_{2} \mathrm{O}$ using the same terms that were applied in the MLR models for $\mathrm{CH}_{4}$, and the results are shown and compared for $35^{\circ} \mathrm{S}$ in Fig. 11 and for $35^{\circ} \mathrm{N}$ in Fig. 12. In order to get a better idea about their mutual changes, their trend profiles are plotted in terms of ppmv decade ${ }^{-1}$. Estimates of uncertainty are shown by the horizontal bars where the trends are highly significant. The trend terms for $\mathrm{H}_{2} \mathrm{O}$ in Fig. 11 are highly significant in the lower stratosphere and also at $0.3 \mathrm{hPa}$. Trends for $\mathrm{H}_{2} \mathrm{O}$ and $\mathrm{CH}_{4}$ are of the same magnitude and weakly positive in the upper stratosphere, but they are not highly significant. There are indications of an anti-correlation in their mutual trends in Fig. 12 for the upper stratosphere of the Northern Hemisphere that are more in keeping with that expected from the chemical oxidation of $\mathrm{CH}_{4}$ to $\mathrm{H}_{2} \mathrm{O}$. Their respective trends also have opposing signs in the lower stratosphere of the Northern Hemisphere, but that finding is attributed to the trends for those two gases in their tropical source region. In that regard, it is noted that the trend profiles for $\mathrm{H}_{2} \mathrm{O}$ in Figs. 11 and 12 qualitatively support the modeled trend estimates of stratospheric $\mathrm{H}_{2} \mathrm{O}$ for the longer time span of 19862010 of Hegglin et al. (2014, their Fig. 5). Their modeled estimates also considered observed trends in tropospheric $\mathrm{CH}_{4}$ plus a chemical conversion to $\mathrm{H}_{2} \mathrm{O}$.

Figure 13 is the MLR model fit to the $\mathrm{CH}_{4}$ time series data at $0.7 \mathrm{hPa}$ of the northern extratropics and subtropics. The minimum in the extratropics occurs in late summer, due to the nearly complete oxidation of the $\mathrm{CH}_{4}$ at that time. Conversely, there is a maximum in the subtropics in late summer due to the upward diabatic circulation that is a dynamical response to the very warm temperatures of the polar summer stratopause (Andrews et al., 1987). Upon closer inspection, one can readily see that these predominant, annual cycle variations in the data of the extratropics are different 

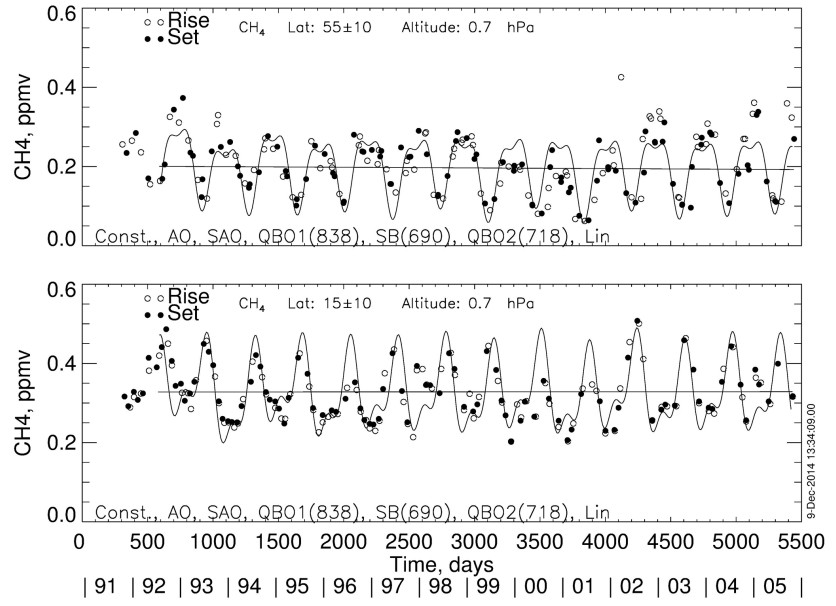

Figure 13. As in Fig. 3, but for $\mathrm{CH}_{4}$ at $0.7 \mathrm{hPa}$ and at the latitudes of $55^{\circ}$ (top) and $15^{\circ}$ (bottom) of the Northern Hemisphere.

for some years; those variations are underestimated by the MLR model terms in 1992 and from 2002-2005 and overestimated from 1999-2001. In the subtropics the late summer maximum is overestimated by the model in 1996 and in 2000-2001. The model clearly underestimates the subtropical data in the winter of 1997-1998, too. Occasional, seasonal amplitude anomalies are also present in the $\mathrm{CH}_{4}$ analyses for the southern subtropics but are nearly absent in the southern extratropics (not shown). It is likely that the more pronounced variations in the Northern Hemisphere are related to the varying planetary wave activity and its effects on the mean meridional transport and mixing of the $\mathrm{CH}_{4}$. Randel et al. (2000) reported that there was a minimum in the stratospheric wave forcing for the years 1993-1997, followed by an increase in 1998-1999. Pawson and Naujokat (1999) also noted that there were no midwinter warming events for the Northern Hemisphere in the middle 1990s. Manney et al. (2005) showed that warming events were more prevalent thereafter.

The seasonal terms of the MLR model simply provide an average fit to the data across all the years. Thus, the time series of HALOE $\mathrm{CH}_{4}$ of the Northern Hemisphere indicate that there must be a connection to effects from aperiodic dynamical forcings. For example, the qualitative effect during and just following a warming event is to enhance meridional transport of a tracer (like $\mathrm{CH}_{4}$ ) in the upper stratosphere and mesosphere. Hitchman and Leovy (1986) also found that there were secondary residual circulations in the subtropics associated with the descent of the SAO that also responded to stratospheric warming events. The MLR models do not account for the effects of such irregular forcings, and those unmodeled effects can affect the analyzed trends. Thus, it may be that the subtropical trends are merely reflecting the effects of changes in stratospheric wintertime warming activity during 1992-2005, rather than representing any longer-term trend for a change of the deep branch of the BDC at those upper levels. It ought to be possible to verify those instances of MLR/data mismatch with the aid of a model study for a $\mathrm{CH}_{4}$-like tracer that is transported with the use of assimilated temperature and ozone fields.

A number of investigators have analyzed time series of $\mathrm{HCl}$ in the lower mesosphere to verify concurrent changes in the effects of reactive chlorine on ozone (e.g., Froidevaux et al., 2006). $\mathrm{HCl}$ is the primary product of the chemical conversion of free chlorine from methyl chloride and from CFC molecules in the upper stratosphere (Brasseur and Solomon, 2005). For this reason $\mathrm{HCl}$ may also be considered as a tracer-like species for studying transport and age-of-air, particularly for the uppermost stratosphere and lower mesosphere. Model studies show peak values of $\mathrm{HCl}$ occurring in the lower mesosphere in 1999, while the $\mathrm{HCl}$ time series from HALOE at $0.46 \mathrm{hPa}$ and up to 2001 indicate that the observed maximum occurred 1-2 years earlier or in 1997 (e.g., Waugh et al., 2001). However, the complete time series of HALOE $\mathrm{HCl}$ shows two maximums - one in 1997 and another from 2001-2002 (WMO, 2007, Figs. 1-12). It may be that there were significant variations in the observed $\mathrm{HCl}$ due to dynamical forcings at those altitudes and that the chemi$\mathrm{cal} /$ transport models do not represent them so well. When the time series of HALOE $\mathrm{HCl}$ are referenced to surfaces of constant $\mathrm{CH}_{4}$, there is better agreement with the modeled trends for $\mathrm{HCl}$ in terms of the known changes in its primary surface source gases or the CFCs (J. Russell III and J. Anderson, Hampton University, personal communication, 2002). Thus, it appears that $\mathrm{HALOE} \mathrm{CH}_{4}$ represents a very effective tracer in the lower mesosphere, even though its mixing ratio there is small.

Spatial gradients for $\mathrm{CH}_{4}$ and $\mathrm{HCl}$ in the lower mesosphere are opposite in sign both vertically and in the meridional direction, such that any anomalies in their respective residuals should have opposing features that would tend to confirm effects from dynamical forcings. Therefore, MLR analyses are applied to time series of both $\mathrm{CH}_{4}$ and $\mathrm{HCl}$ in the lower mesosphere. As shown in Fig. $13, \mathrm{CH}_{4}$ has seasonal and QBO-like forcings that are resolved and accounted for reasonably well with the MLR models; the same terms are applied to the HALOE $\mathrm{HCl}$ time series. A quadratic term is also added to the linear term for its MLR model because $\mathrm{HCl}$ varies non-linearly from $1992-2005$. At $55 \pm 10^{\circ} \mathrm{N}$ and $0.7 \mathrm{hPa}$ (near $52 \mathrm{~km}$ ) the mixing ratio of $\mathrm{HCl}$ increases from $2.6 \mathrm{ppbv}$ in 1992 to a maximum of $3.6 \mathrm{ppbv}$ in 2001 and then declines to an average of $3.1 \mathrm{ppbv}$ in $2005 ; \mathrm{CH}_{4}$ at $0.7 \mathrm{hPa}$ is more nearly constant or $0.21 \mathrm{ppmv}$ over that time span.

Figure 14 (top) shows the time series of the residuals for $\mathrm{HCl}$ for $55^{\circ} \mathrm{N}$ and at $0.7 \mathrm{hPa}$. The residuals (or data minus MLR model curve values) are obtained in this case by setting the AR-1 coefficient to zero, giving a better idea of anomalies for the modeled results. In general, the $\mathrm{HCl}$ residuals indicate a good fit to the data, varying between $\pm 0.2 \mathrm{ppbv}$ or within $6 \%$ of the mean for the data. Note though that the residu- 

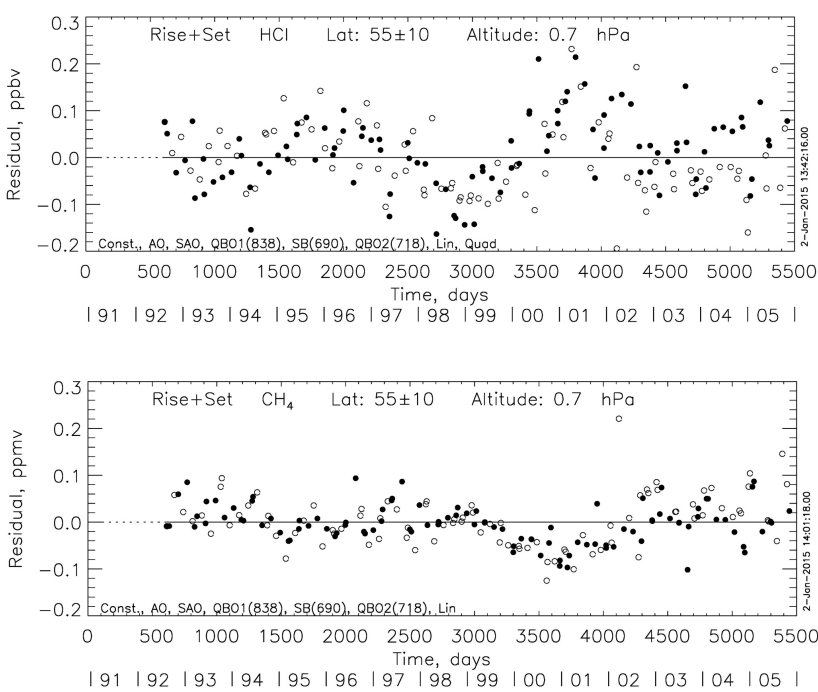

Figure 14. (Top) time series of $\mathrm{HCl}$ residual (data - MLR curve) at $0.7 \mathrm{hPa}$ and at $55^{\circ} \mathrm{N}$; (bottom) time series of $\mathrm{CH}_{4}$ residual at $55^{\circ} \mathrm{N}$.

als are mostly negative in 1998 and 1999 and mostly positive in 1995-1996 and in 2001-2002. Figure 14 (bottom) shows the corresponding residuals for $\mathrm{CH}_{4}$ that are of the order of \pm 0.06 ppmv or about $29 \%$ of its mean value; those residuals indicate little to no bias with the model from 1992 to mid-1999, but then show a clear negative bias in 2000 and 2001, or opposite to that from $\mathrm{HCl}$. Thus, there is aperiodic structure remaining in the residuals for both $\mathrm{HCl}$ and $\mathrm{CH}_{4}$, and their opposing signs during some years indicate that a net transport may have been induced by the effects of wave forcings during those winters having significant stratospheric warming activity. Recently though, Damiani et al. (2014) reported that there can also be a chemical re-partitioning of $\mathrm{HCl}$ to $\mathrm{ClONO}_{2}$ in response to a lower mesospheric cooling following stratospheric warming events. The absence of any clear anti-correlation between the $\mathrm{HCl}$ and $\mathrm{CH}_{4}$ residuals of Fig. 14 for 1998-1999 indicates that $\mathrm{HCl}$ is not strictly a passive tracer at that time but may be depleted slightly by the chemical repartitioning. That prospect might also explain the small, but anomalous decrease in the HALOE $\mathrm{HCl}$ trends of 1998-1999 that were reported in WMO (2007).

\section{Conclusions}

Time series data of the tracer-like molecule $\mathrm{CH}_{4}$ obtained with the UARS HALOE experiment are analyzed using MLR techniques for their periodic and trend terms during 1992 2005. The sunset and sunrise profile data are binned according to tropical and high-latitude zones of both the Southern Hemisphere and the Northern Hemisphere. The time series are generated and analyzed from 50 to $0.4 \mathrm{hPa}$. Based on an examination of the data time series, both seasonal and interannual terms are included in the MLR models, in addition to a linear trend term. The trend terms are examined to see whether there is any change in the BDC for the Southern Hemisphere or the Northern Hemisphere during 1992-2005 in accordance with the simple concept of Plumb (2007) for a hemispheric BDC. The adoption of that approach indicates that a change of the BDC can be detected where the $\mathrm{CH}_{4}$ trends are positive by more than $3 \%$ decade $^{-1}$ in the tropics and less than that or negative at the high latitudes. Further, since the analyses are conducted at pressure levels rather than at geometric altitudes, it is presumed that any significant trends must be due mainly to changes from the effects of wave forcings on the distributions of $\mathrm{CH}_{4}$.

The primary findings of this study are as follows. The $\mathrm{CH}_{4}$ trend terms for the Northern Hemisphere are significant and positive from 50 to $7 \mathrm{hPa}$ at $10^{\circ} \mathrm{N}$ and larger than the tropospheric $\mathrm{CH}_{4}$ trends of about $3 \%$ decade $^{-1}$ from 20 to $7 \mathrm{hPa}$. At $60^{\circ} \mathrm{N}$ the trends are clearly negative from 20 to $7 \mathrm{hPa}$. Thus, the overall trend signature across those two zones indicates an acceleration of the BDC in the middle stratosphere of the Northern Hemisphere. The $\mathrm{CH}_{4}$ trends are positive and significant from 10 to $5 \mathrm{hPa}$ for $10^{\circ} \mathrm{S}$, and the corresponding trends are negative at 7 and $5 \mathrm{hPa}$ for $60^{\circ} \mathrm{S}$ but not highly significant; their combined trends do not clearly indicate an acceleration of the BDC for the middle stratosphere of the Southern Hemisphere. No significant change is indicated for the BDC at 50 and $30 \mathrm{hPa}$, although the analyzed $\mathrm{CH}_{4}$ trends are asymmetric between the two hemispheres. The $\mathrm{CH}_{4}$ trends are also not highly significant for the stratosphere of either hemisphere above the $5 \mathrm{hPa}$ level. The early climate model simulations of Rind et al. (1990) are qualitatively consistent with these findings, in that their model runs show more wave activity and dissipation throughout the winter in the Northern Hemisphere than in the Southern Hemisphere for their model scenario of steady increases of $\mathrm{CO}_{2}$ in the atmosphere. Still, it may be that these findings of changes in the BDC are only representative of 1992-2005, particularly for the middle latitudes of the Northern Hemisphere.

The trends for $\mathrm{HALOE} \mathrm{H}_{2} \mathrm{O}$ are compared at $35^{\circ}$ latitude with those from $\mathrm{CH}_{4}$ in the upper stratosphere and lower mesosphere because $\mathrm{H}_{2} \mathrm{O}$ is the primary product of the oxidation of $\mathrm{CH}_{4}$ at those altitudes. An approximate inverse relationship between their trends is found in the middle and upper stratosphere of the Northern Hemisphere, but not in the Southern Hemisphere. The two gases show inverse trends in the lower stratosphere, too. However, while the trends for HALOE $\mathrm{H}_{2} \mathrm{O}$ are large and significant in the lower stratosphere, they reflect mostly the episodic decrease for the entry-level $\mathrm{H}_{2} \mathrm{O}$ to the stratosphere from below in 2000-2001.

The variation of $\mathrm{CH}_{4}$ with time in the lower mesosphere also provides some clues about the effects of aperiodic wave forcings in that region. Other researchers have also reported that there are modest disagreements in the modeled trends for $\mathrm{HCl}$ compared to those observed with HALOE, particularly from about 1996 to 2002. Both $\mathrm{CH}_{4}$ and $\mathrm{HCl}$ should 
serve as tracers of any changes due to the wave forcings. In most instances their respective time series residuals are anticorrelated and support the idea of a dynamical response to wave activity. The observed, small reductions of the $\mathrm{HCl}$ in the lower mesosphere for 1998-1999, however, do not seem to be related to a corresponding increase in the $\mathrm{CH}_{4}$ residuals. A chemical re-partitioning of $\mathrm{HCl}$ to $\mathrm{ClONO}_{2}$ may have occurred at that time. In summary, it is concluded that nearglobal distributions of $\mathrm{CH}_{4}$, as remotely measured from a satellite, are an excellent diagnostic of the effects of seasonal and longer-term changes for the total transport within the middle atmosphere.

Acknowledgements. Figure 1 is attributed to Ted Shepherd, Doug Degenstein, and the Optical Spectrograph and InfraRed Imager System (OSIRIS) satellite experiment team. Figure 2 was kindly provided by Eric Fleming of SSAI and NASA Goddard. The author (EER) appreciates the insightful and helpful comments about his manuscript by the two reviewers. EER carried out this work while serving as a Distinguished Research Associate within the Science Directorate at NASA Langley.

Edited by: P. Haynes

\section{References}

Al-Saadi, J. A., Pierce, R. B., Fairlie, T. D., Kleb, M. M., Eckman, R. S., Grose, W. L., Natarajan, M., and Olsen, J. R.: Response of middle atmosphere chemistry and dynamics to volcanically elevated sulfate aerosol: three-dimensional coupled model simulations, J. Geophys. Res., 106, 27255-27275, 2001.

Andrews, D. G., Holton, J. R., and Leovy, C. B.: Middle atmosphere dynamics, Academic Press, Inc., Orlando, Florida, 489 pp., 1987.

Baldwin, M. P. and Dunkerton, T. J.: Biennial, quasi-biennial, and decadal oscillations of potential vorticity in the northern stratosphere, J. Geophys. Res., 103, 3919-3928, 1998.

Birner, T. and Bönisch, H.: Residual circulation trajectories and transit times into the extratropical lowermost stratosphere, Atmos. Chem. Phys., 11, 817-827, doi:10.5194/acp-11-817-2011, 2011.

Bönisch, H., Engel, A., Birner, Th., Hoor, P., Tarasick, D. W., and Ray, E. A.: On the structural changes in the Brewer-Dobson circulation after 2000, Atmos. Chem. Phys., 11, 3937-3948, doi:10.5194/acp-11-3937-2011, 2011.

Brasseur, G. and Solomon, S.: Aeronomy of the middle atmosphere, 3rd Edition, in Atmospheric and Oceanographic Sciences Library, Vol. 32, Springer, the Netherlands, 644 pp., 2005.

Butchart, N.: The Brewer-Dobson circulation, Rev. Geophys., 52, 157-184, 2014.

Considine, D. B., Rosenfield, J. E., and Fleming, E. L.: An interactive model study of the influence of the Mount Pinatubo aerosol on stratospheric methane and water trends, J. Geophys. Res., 106, 27711-27727, 2001.

Damiani, A., Funke, B., Lopez-Puertas, M., Gardini, A., von Clarmann, T., Santee, M. L., Froidevaux, L., and Cordero, R. R.: Changes in the composition of the northern polar upper stratosphere in February 2009 after a sudden stratospheric warming, J.
Geophys. Res., 119, 11429-11444, doi:10.1002/2014JD021698, 2014.

Diallo, M., Legras, B., and Chédin, A.: Age of stratospheric air in the ERA-Interim, Atmos. Chem. Phys., 12, 12133-12154, doi:10.5194/acp-12-12133-2012, 2012.

Dlugokencky, E. J., Walter, B. P., Masarie, K. A., Lang, P. M., and Kasischke, E. S.: Measurements of an anomalous global methane increase during 1998, Geophys. Res. Lett., 28, 499-502, 2001.

Dlugokencky, E. J., Bruhwiler, L., White, J. W. C., Emmons, L. K., Novelli, P. C., Montzka, S. A., Masarie, K. A., Lang, P. M., Crotwell, A. M., Miller, J. B., and Gatti, L. V.: Observational constraints on recent increases in the atmospheric $\mathrm{CH}_{4}$ burden, Geophys. Res. Lett., 36, L18803, doi:10.1029/2009GL039780, 2009.

Dunkerton, T. J.: On the mean meridional mass motions of the stratosphere and mesosphere, J. Atmos. Sci., 35, 2325-2333, 1978.

Dunkerton, T. J.: Quasi-biennial and subbiennial variations of stratospheric trace constituents derived from HALOE observations, J. Atmos. Sci., 58, 7-25, 2001.

Fleming, E. L., Jackman, C. H., Stolarski, R. S., and Considine, D. B.: Simulation of stratospheric tracers using an improved empirically based two-dimensional model transport formulation, J. Geophys. Res., 104, 23911-23934, 1999.

Froidevaux, L., Livesey, N. J., Read, W. G., Salawitch, R. J., Waters, J. W., Brouin, B., MacKenzie, I. A., Pumphrey, H. C., Bernath, P., Boone, C., Nassar, R., Montzka, S., Elkins, J., Cunnold, D., and Waugh, D.: Temporal decrease in upper atmospheric chlorine, Geophys. Res. Lett., 33, L23812, doi:10.1029/2006GL027600, 2006.

Fueglistaler, S.: Stepwise changes in stratospheric water vapor?, J. Geophys. Res., 117, D13302, doi:10.1029/2012JD017582, 2012.

Garcia, R. R., Randel, W. J., and Kinnison, D. E.: On the determination of age of air trends from atmospheric trace species, J. Atmos. Sci., 68, 139-154, doi:10.1175/2010JAS3527.1, 2011.

Garny, H., Birner, T., Boenisch, H., and Bunzel, F.: The effects of mixing on age of air, J. Geophys. Res., 119, 7015-7034, doi:10.1002/2013JD021417, 2014.

Gordley, L. L., Thompson, E., McHugh, M., Remsberg, E., Russell III, J., and Magill, B.: Accuracy of atmospheric trends inferred from the halogen occultation experiment, J. Appl. Remote Sens., 3, 033526, doi:10.1117/1.3131722, 2009.

Gray, L. J. and Russell III, J. M.: Interannual variability of trace gases in the subtropical winter stratosphere, J. Atmos. Sci., 56, 977-993, 1999.

Hall, T. M. and Plumb, R. A.: Age as a diagnostic of stratospheric transport, J. Geophys. Res., 99, 1059-1070, 1994.

Haynes, P. H., Marks, C. J., McIntyre, M. E., Shepherd, T. G., and Shine, K. P.: On the "downward control" of extratropical diabatic circulations by eddy-induced mean zonal forces, J. Atmos. Sci., 48, 651-678, 1991.

Hegglin, M. I., Plummer, D. A., Shepherd, T. G., Scinocca, J. F., Anderson, J., Froidevaux, L., Funke, B., Hurst, D., Rozanov, A., Urban, J., von Clarmann, T., Walker, K. A., Wang, H. J., Tegtmeier, S., and Weigel, K.: Vertical structure of stratospheric water vapour trends derived from merged satellite data, Nat. Geosci., 7, 768-776, doi:10.1038/ngeo2236, 2014. 
Hitchman, M. H. and Leovy, C. B.: Evolution of the zonal mean state in the equatorial middle atmosphere during October 1978May 1979, J. Atmos. Sci., 43, 3159-3176, 1986.

Holton, J. R.: Meridional distribution of stratospheric trace constituents, J. Atmos. Sci., 43, 1238-1242, 1986.

Holton, J. R. and Choi, W.-K.: Transport circulation deduced from SAMS trace species data, J. Atmos. Sci., 45, 1929-1939, 1988.

Lin, P. and Fu, Q.: Changes in various branches of the BrewerDobson circulation from an ensemble of chemistry climate models, J. Geophys. Res., 118, 73-84, doi:10.1029/2012JD018813, 2013.

Manney, G. L., Zurek, R. W., O’Neill, A., and Swinbank, R.: On the motion of air through the stratospheric polar vortex, J. Atmos. Sci., 51, 2973-2994, 1994.

Manney, G. L., Krüger, K., Sabutis, J. L., Sena, S. A., and Pawson, S.: The remarkable 2003-2004 winter and other recent warm winters in the Arctic stratosphere since the late 1990s, J. Geophys. Res., 110, D04107, doi:10.1029/2004JD005367, 2005.

Monge-Sanz, B. M., Chipperfield, M. P., Dee, D. P., Simmons, A. J., and Uppala, S. M.: Improvements in the stratospheric transport achieved by a chemistry transport model with ECMWF (re)analyses: identifying effects and remaining challenges, Q. J. Roy. Meteorol. Soc., 139, 654-673, 2013.

Nedoluha, G. E., Siskind, D. E., Bacmeister, J. T., Bevilacqua, R. M., and Russell III, J. M.: Changes in upper stratospheric $\mathrm{CH}_{4}$ and $\mathrm{NO}_{2}$ as measured by HALOE and implications for changes in transport, Geophys. Res. Lett., 35, 987-990, 1998.

Neu, J. L., Sparling, L. C., and Plumb, R. A.: Variability of the subtropical "edges" in the stratosphere, J. Geophys. Res., 108, 4482, doi:10.1029/2002JD002706, 2003.

Okamoto, K., Sato, K., and Akiyoshi, H.: A study on the formation and trend of the Brewer-Dobson circulation, J. Geophys. Res., 116, D10117, doi:10.1029/2010JD014953, 2011.

Palazzi, E., Fierli, F., Stiller, G. P., and Urban, J.: Probability density functions of long-lived tracer observations from satellite in the subtropical barrier region: data intercomparison, Atmos. Chem. Phys., 11, 10579-10598, doi:10.5194/acp-11-10579-2011, 2011.

Park, J. H., Russell III, J. M., Gordley, L. L., Drayson, S. R., Benner, D. C., McInerney, J. M., Gunson, M. R., Toon, G. C., Sen, B., Blavier, J.-F., Webster, C. R., Zipf, E. C., Erdman, P., Schmidt, U., and Schiller, C.: Validation of halogen occultation experiment $\mathrm{CH}_{4}$ measurements from the UARS, J. Geophys., Res., 101, 10183-10203, 1996.

Pawson, S. and Naujokat, B.: The cold winters of the middle 1990s in the northern lower stratosphere, J. Geophys. Res., 104, 14209 14222, 1999.

Ploeger, F., Riese, M., Haenel, F., Konopka, P., Müller, R., and Stiller, G.: Variability of stratospheric mean age of air and of the local effects of residual circulation and eddy mixing, J. Geophys. Res., 120, 716-733, doi:10.1002/2014JD022468, 2015a.

Ploeger, F., Abalos, M., Birner, T., Konopka, P., Legras, B., Müller, R., and Riese, M.: Quantifying the effects of mixing and residual circulation on trends of stratospheric mean age of air, Geophys. Res. Lett., doi:10.1002/2014GL062927, 2015b.

Plumb, R. A.: Tracer interrelationships in the stratosphere, Rev. Geophys., 45, RG4005, doi:10.1029/2005RG000179, 2007.

Plumb, R. A. and Ko, M. K. W.: Interrelationships between mixing ratios of long-lived stratospheric constituents, J. Geophys. Res., 97, 10145-10156, 1992.
Randel, W. J., Wu, F., Russell III, J. M., Roche, A., and Waters, J. W.: Seasonal cycles and QBO variations in stratospheric $\mathrm{CH}_{4}$ and $\mathrm{H}_{2} \mathrm{O}$ observed in UARS HALOE data, J. Atmos. Sci., 55, 163-185, 1998.

Randel, W. J., Wu, F., Russell III, J. M., and Waters, J.: Spacetime patterns of trends in stratospheric constituents derived from UARS measurements, J. Geophys. Res., 104, 3711-3727, 1999.

Randel, W. J., Wu, F., Russell III, J. M., Zawodny, J. M., and Nash, J.: Interannual changes in stratospheric constituents and global circulation derived from satellite data, in: Atmospheric Science Across the Stratopause, edited by: Siskind, D. E., Eckermann, S. D., and Summers, M. E., American Geophysical Union, Washington, D.C., 271-285, doi:10.1029/GM123p0271, 2000.

Randel, W. J., Wu, F., Voemel, H., Nedoluha, G. E., and Forster, P.: Decreases in stratospheric water vapor after 2001: links to changes in the tropical tropopause and the Brewer-Dobson circulation, J. Geophys. Res., 111, D12312, doi:10.1029/2005JD006744, 2006.

Ray, E. A., Moore, F. L, Rosenlof, K. H., Davis, S. M., Sweeney, C., Tans, P., Wang, T., Elkins, J. W., Bönisch, H., Engel, A., Sugawara, S., Nakazawa, T., and Aoki, S.: Improving stratospheric transport trend analysis based on $\mathrm{SF}_{6}$ and $\mathrm{CO}_{2}$ measurements, $\mathrm{J}$. Geophys. Res., 119, 14110-14128, doi:10.1002/2014JD021802, 2014.

Remsberg, E. E.: On the response of Halogen Occultation Experiment (HALOE) stratospheric ozone and temperature to the 11-yr solar cycle forcing, J. Geophys. Res., 113, D22304, doi:10.1029/2008JD010189, 2008.

Remsberg, E. E.: Trends and solar cycle effects in temperature versus altitude from the halogen occultation experiment for the mesosphere and upper stratosphere, J. Geophys. Res., 114, D12303, doi:10.1029/2009JD011897, 2009.

Remsberg, E.: Observed seasonal to decadal scale responses in mesospheric water vapor, J. Geophys. Res., 115, D06306, doi:10.1029/2009JD012904, 2010.

Remsberg, E. E. and Deaver, L. E.: Interannual, solar cycle, and trend terms in middle atmospheric temperature time series from HALOE, J. Geophys. Res., 110, D06106, doi:10.1029/2004JD004905, 2005.

Rind, D., Suozzo, R., Balachandran, N. K., and Prather, M. J.: Climate changes and the middle atmosphere. Part I: the doubled $\mathrm{CO}_{2}$ climate, J. Atmos. Sci., 47, 475-494, 1990.

Rosenlof, K. H.: Transport changes inferred from HALOE water and methane measurements, J. Meteorol. Soc. Jpn., 80, 4B, 831848, 2002.

Ruth, S., Kennaugh, R., Gray, L. J., and Russell III, J. M.: Seasonal, semiannual, and interannual variability seen in measurements of methane made by the UARS Halogen Occultation Experiment, J. Geophys. Res., 102, 16189-16199, 1997.

Scherer, M., Vömel, H., Fueglistaler, S., Oltmans, S. J., and Staehelin, J.: Trends and variability of midlatitude stratospheric water vapour deduced from the re-evaluated Boulder balloon series and HALOE, Atmos. Chem. Phys., 8, 1391-1402, doi:10.5194/acp8-1391-2008, 2008.

Schoeberl, M. R., Sparling, L. C., Jackman, C. H., and Fleming, E. L.: A Lagrangian view of stratospheric trace gas distributions, J. Geophys. Res., 105, 1537-1552, 2000.

Shaw, T. A. and Shepherd, T. G.: Raising the roof, Nat. Geosci., 1, 12-13, 2008. 
Shepherd, T. G.: Transport in the middle atmosphere, J. Meteorol. Soc. Jpn., 85B, 165-191, 2007.

Shu, J., Tian, W., Hu, D., Zhang, J., Shang, L., Tian, H., and Xie, F.: Effects of the quasi-biennial oscillation and stratospheric semiannual oscillation on tracer transport in the upper stratosphere, J. Atmos. Sci., 70, 1370-1389, doi:10.1175/JAS-D-12053.1, 2013.

Solomon, S., Kiehl, J. T., Garcia, R. R., and Grose, W.: Tracer transport by the diabatic circulation deduced from satellite observations, J. Atmos. Sci., 43, 1603-1617, 1986.

Stanford, J. L. and Ziemke, J. R.: $\mathrm{CH}_{4}$ and $\mathrm{N}_{2} \mathrm{O}$ photochemical lifetimes in the upper stratosphere: in situ estimates using SAMS data, Geophys. Res. Lett., 18, 677-680, 1991.

Stanford, J. L., Ziemke, J. R., and Gao, S. Y.: Stratospheric circulation features deduced from SAMS constituent data, J. Atmos. Sci., 50, 226-246, 1993.

Stiller, G. P., von Clarmann, T., Haenel, F., Funke, B., Glatthor, N., Grabowski, U., Kellmann, S., Kiefer, M., Linden, A., Lossow, S., and López-Puertas, M.: Observed temporal evolution of global mean age of stratospheric air for the 2002 to 2010 period, Atmos. Chem. Phys., 12, 3311-3331, doi:10.5194/acp-12-33112012, 2012.

Thomason, L. W.: Toward a combined SAGE II-HALOE aerosol climatology: an evaluation of HALOE version 19 stratospheric aerosol extinction coefficient observations, Atmos. Chem. Phys., 12, 8177-8188, doi:10.5194/acp-12-8177-2012, 2012.
Thompson, R. E. and Gordley, L. L.: Retrieval algorithms for the halogen occultation experiment, NASA/CR-2009-215761, available at: http://www.sti.nasa.gov (last access: 31 March 2015), 2009.

Tiao, G. C., Reinsel, G. C., Xu, D., Pedrick, J. H., Zhu, X., Miller, A. J., DeLuisi, J. J., Mateer, C. L., and Wuebbles, D. J.: Effects of autocorrelation and temporal sampling schemes on estimates of trend and spatial correlation, J. Geophys. Res., 95, 20507-20517, doi:10.1029/JD095iD12p20507, 1990.

Volk, C. M., Elkins, J. W., Fahey, D. W., Dutton, G. S., Gilligan, J. M., Loewenstein, M., Podolske, J. R., Chan, K. R., and Gunson, M. R.: Evaluation of source gas lifetimes from stratospheric observations, J. Geophys. Res., 102, 25543-25564, 1997.

Waugh, D. W., Considine, D. B., and Fleming, E. L.: Is upper stratospheric chlorine decreasing as expected?, Geophys. Res. Lett., 28, 1187-1190, 2001.

WMO (World Meteorological Organization): Scientific assessment of ozone depletion: 2006, Global Ozone Research and Monitoring Project, Report No. 50, Geneva, Switzerland, 2007.

Youn, D., Choi, W., Lee, H., and Wuebbles, D. J.: Interhemispheric differences in changes of long-lived tracers in the middle stratosphere over the last decade, Geophys. Res. Lett., 33, L03807, doi:10.1029/2005GL024274, 2006. 